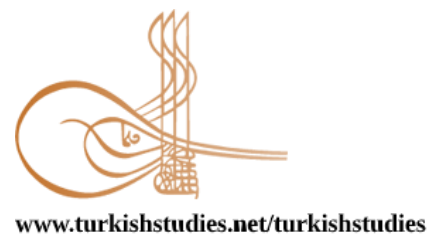

Turkish Studies

\title{
Covid-19 Pandemi Dönemi Uzaktan Eğitim Sürecinde Öğretmen Görüşlerine Göre Türkçe Ĕgitimi
}

\author{
Turkish Education During Covid-19 Pandemic Distance Education Process
}

\author{
Yavuz Selim Bayburtlu*
}

\begin{abstract}
This study was conducted to identify the status of Turkish education and the views of Turkish teachers during the Covid-19 pandemic distance education process. 30 Turkish teachers from central provinces of the city of Antalya participated in the study. Turkish teachers were asked questions using a semi-structured interview form prepared in alignment with expert opinions. The results of this study are significant in terms of testing the status of our education system when there is a need for suspending education due to earthquakes which happen frequently in our country and the current pandemic, and managing remote education processes better by identifying obstacles and issues that can be faced in these situations. It was found that $87 \%$ of the Turkish teachers participated in the study tried to teach lessons, that they interacted with students and parents by using various social messaging applications, using various video lessons available to keep students engaged during the pandemic in which schools were suspended. Teachers stated that some students could not attend live classes as they did not have devices such as computers or tablets. Challenges such as connection issues of the EBA live lesson application and time limitations decreased over time, according to participants' statements. Turkish teachers stated that some parents were not interested during this process, that they didn't monitor students when working on computers, and especially in cases where both parents worked, their children were not controlled during the process. Teachers stating that this process caused screen addiction in some students also said that parents should be trained on this subject matter. Turkish teachers stated that students' attendance levels were not at the desired level. Turkish teachers who participated in the study stated that Turkish textbooks should be interactive with the EBAeducation network, and that it would be beneficial to arrange the content of the textbook in the context of digital content. It was also stated that it would be beneficial for Turkish teachers to receive training on digital content development. It was stated that the infrastructure of the EBA education network should be strengthened so that all students can benefit at the same time and at any time. Turkish teachers stated that it would be beneficial to develop digital applications and stories that would increase students' interest in reading books.
\end{abstract}

\section{Structured Abstract: Introduction}

Planning and implementation of educational activities is extremely important in situations where face-to-face education needs to be suspended due to reasons such as earthquakes, epidemic diseases, terrorism and social events etc. Having an alternative method of educational activities in such sudden

\footnotetext{
*Dr. Türkçe Öğretmeni, Millî Eğitim Bakanlığı.

Turkish Teacher, Ministry of National Education.

ORCID 0000- 0002- 6128-6239

yavuz.selim.07@hotmail.com

Cite as/ Atıf: Bayburtlu, Y.S. (2020). Covid-19 pandemi dönemi uzaktan eğitim sürecinde öğretmen görüşlerine göre Türkçe eğitimi. Turkish Studies, 15(4), 131-151. https://dx.doi.org/10.7827/TurkishStudies.44460

Received/Geliş: 23 June/Haziran 2020

Checked by plagiarism software

Accepted/Kabul: 10 August/Ağustos 2020

Published/Yayın: 30 August/Ağustos 2020

Copyright $(\mathrm{C}$ MDE, Turkey

CC BY-NC 4.0
} 
situations, would allow education to continue. Remote education through television in our country started with the television lessons of Anadolu University in 1982 (Kunç and Varol, 1994). In addition, distance education activities are routinely continuing. In some universities, classes can be done interactively and in virtual platforms. Universities establish distance education centers to plan these activities and turn some of the face-to-face trainings into distance education activities. The Ministry of National Education has closely followed the technological developments in the world and created the infrastructure of digital applications in education with different applications such as Fatih Project, EBA Information Network and tablet computer distribution to students. These applications indicate that most of the educational activities will take place in digital environments in the future. EBA Informatics Network site contains lectures, videos, questions about each course taught in schools. Teachers can assign their students homework on this site and follow their academic development. Through EBA, teachers can hold live lessons with their students. During periods when education was interrupted dues to natural disasters such as earthquakes in our country, students were provided with education support via distance education. The latest example of this was seen in the Elâzı ̆, Van and Malatya earthquakes. Students whose schools were closed continued their education through the Education Information Network (EBA) system established by the Ministry of Education (EBA, 2020). Distance education provides students with equal opportunities (Yalın, 2009). When research on distance education in the literature is reviewed, it is seen that there are negative views as well as positive views on this issue. The results of a study by Birişçi (2013) determined distance learning applications of students and their opinions, it was seen that negative student views about distance education application were high. In the study of Arslan and Şahin (2013), teachers expressed negative opinions about the in-service training courses via distance education due to the weak interaction opportunities. In Inan's (2013) study, instructors stated that distance education is beneficial. Today, the majority of students who use the EBA Information Network system, which is a system portal where distance education activities are conducted, stated that the EBA site is very useful in terms of homework, study, lesson repetition, preparation for the lesson and studying for exams (Tüysüz ve Çümen, 2016, p.292). It has been stated by various researchers that the EBA network system contributes to students (Aktay and Keskin, Aydınözü, Sözcü and Akbaş 2016). This application covering three cities had to be implemented all around Turkey and even in several countries in the world due to the Covid-19 pandemic process. With the pandemic announcement of the World Health Organization, schools were shut down. The education was suspended and continued in the form of distance education. What is important here is to monitor how this process works and to reveal the problems that students and teachers experience during the distance education process. Determining the problems encountered in the distance education process and developing solution suggestions quickly will help the process to proceed in a healthy way. Identifying the technical problems experienced, the problems arising from the teacher and students in the distance education process, and developing solutions in this direction will contribute to the improvement of the distance education infrastructure. For this purpose, this study was conducted to determine the status of Turkish education in the Covid-19 pandemic distance education process. In the event of such national or international disasters, it is thought that uncovering the problems related to Turkish education during distance education in our country will guide and contribute to future distance education activities. Deficiencies detected in this process will guide remedial training. Remedial education planned would be carried out more effectively and purposefully in alignment with the solution recommendations developed based on research. The main purpose of distance education is to address the entire target audience of distance education activities and to enable all students to benefit from educational activities.

\section{Purpose}

For the purpose of the study, opinions of Turkish teachers were asked to determine the status of Turkish education during the Covid-19 pandemic distance education process. In alignment with this purpose, the following questions were asked of the Turkish teachers participating in the study.

1. What is the status of Turkish education during the Covid-19 distance education process and what did you do in the process? Please explain briefly.

2. What are the problems you encountered duing the Covid-19 pandemic distance education process and what are your solution recommendations?

3. What is the level of participation of students in live Turkish lessons during the distance education process? Please compare it with in-class lessons. What can be done to increase participation? 
4. How did the distance education process affect students' interest in Turkish lessons? How do you think the process affect students' academic success?

5.Please share your opinions on the education portal or program you used during the Covid-19 pandemic distance education. In your opinion, could there be a higher quality system/how would it be? What could be included in the system?

6.Did you receive positive or negative feedback from parents in relation to your lessons during the Covid-19 pandemic distance eduation process? Please explain.

7.How do you think the process would continue after this? Can lessons be taught via distance education? How do you see the status of teachers in the upcoming years? Should Turkish textbooks be re-addressed in alignment with the process of distance education? Later in the process, do you think students could have virtual homework or tasks, etc. in certain parts of their textbooks?

\section{Method}

This study is qualitative in design using a case study approach. The most prominent characteristic of case studies is that it offers the opportunity to scrutinize detailedinformation that may not be examined with different methods (Punch, 2014). A qualitative case study was preferred as the purpose of the study was to examine the status of Turkish education during Covid-19 pandemic in detail (Yıldırım \& Şimşek, 2018). In the study, Turkish teachers' opinions on the process of distance education were sought and the process was evaluated comprehensively in all aspects.

\section{Results}

When the results of the study are evaluated in general, it is seen that the distance education system implemented by the ministry has infrastructure deficiencies. All students logging in the education portal at the same time caused the system to crash. For this, the system should be strengthened by performing infrastructure and maintenance upgrades. Our education system should be ready for distance education at any time. When education is disrupted for reasons such as earthquake, flood and epidemic diseases, distance education should be activated immediately and carried out smoothly. Students having computers or tablets and internet access is very important in terms of implementing distance education based on the equality principle. As in previous years, tablet computers can be distributed to students. The results of the study revealed that Turkish textbooks have deficiencies in terms of suitability for digital content and the EBA education portal. According to the results of the study, Turkish teachers want Turkish textbooks to be restructured in a way that is integrated with the EBA education portal. At this point, Turkish textbooks should be organized in such a way that they're integrated into the system and that distance education can always be carried out. Since the Turkish teachers participating in the study stated that they had lack of knowledge in digital content development, it would be very useful to provide teachers with digital content development training. It is very important to update Turkish textbooks in terms of digital content that can be compatible with computers, tablets and smartphones, and various digital applications. The results of the study showed that students face the problem of screen addiction in the distance education process. In order to eliminate its negative effects, it would be beneficial to provide training to students and parents. Developing digital stories to increase students' reading levels, developing reading apps to increase their interest in reading, and conducting studies on this subject would be very useful in terms of reading habits.

Keywords: Distance Turkish education, Turkish education during pandemic, Covid-19 Turkish education, distance education, EBA Turkish course

Öz: Bu çalışma, Türkçe öğretmenlerinin görüşleri aracıllığılla pandemi döneminde Türkçe eğitiminin durumunu ortaya koymak amacıyla yürütülmüştür. Araştırmaya Antalya merkez ilçelerinden 30 Türkçe öğretmeni katılmıştır. Türkçe öğretmenlerine uzman görüşleri doğrultusunda geliştirilen yarı yapılandırılmış görüşme formu ile sorular yöneltilmiştir. Türkiye'de sık sık doğal afetler yaşanmaktadır. Depremler, salgın hastalıklar ve çeşitli doğal afetlerin yaşandığı dönemlerde okulların tatil edilmesi, eğitime ara verilmesi gerektiği durumlarda eğitim sistemimizin durumunun test edilebilmesi, bu tür durumlarda yaşanabilecek aksaklıkların ve sorunların tespit edilerek uzaktan eğitim süreçlerinin daha sağlıklı yürütülebilmesi adına bu çalışmada tespit edilen sonuçların önemli olduğu düşünülmektedir. Araştırmaya katılan Türkçe öğretmenlerinin \%87'sinin okulların tatil edildiği pandemi döneminde Türkçe derslerini işlemeye çalıştığı, 
öğrencilerin Türkçe eğitiminden kopmamaları için imkânlar dâhilinde çeşitli video ders programlarını, sosyal mesajlaşma uygulamalarını kullanarak öğrenciler ve öğrenci velileri ile iletişim halinde oldukları anlaşılmıştır. Araştırmaya katılan öğretmenler öğrencilerin bir kısmında bilgisayar, tablet gibi cihazların olmayışından canlı derslere katılamadıklarını ifade etmiştir. EBA canlı ders uygulamasının bağlantı sorunları, zaman sınırlaması gibi çeşitli aksaklıklarının olduğunu ifade eden katılımcılar bu olumsuzlukların zaman içinde azaldığını ifade etmiştir. Türkçe öğretmenleri velilerin bir kısmının bu süreçte ilgisiz olduğunu, öğrencileri bilgisayar başındayken takip etmediklerini, özellikle her ikisi de çalışan velilerin çocuklarının süreç için kontrolsüz kaldığını ifade etmiştir. Bu sürecin bazı öğrencilerde ekran bağımlılığı oluşmasına neden olduğunu ifade eden öğretmenler velilerin de bu konuda eğitilmesi gerektiğini belirtmiştir. Türkçe öğretmenleri öğrencilerin derslere katılım düzeylerinin istenilen seviyede olmadığını ifade etmiştir. Araştırmaya katılan Türkçe öğretmenleri Türkçe ders kitaplarının EBA eğitim ağıyla etkileşimli olması gerektiğini, ders kitabı içeriğinin dijital içerikler bağlamında düzenlenmesinin faydalı olacağını ifade etmiştir. Ayrıca Türkçe öğretmenlerinin dijital içerik geliştirme konusunda eğitim almalarının faydalı olacağı ifade edilmiştir. Eba eğitim ağının tüm öğrencilerin aynı anda ve istedikleri saatte faydalanabileceği şekilde alt yapısının güçlendirilmesi gerektiği belirtilmiştir.

Anahtar Kelimeler: Pandemi, uzaktan eğitim, Türkçe eğitimi, uzaktan Türkçe eğitimi,

İnsanları belirlenen amaçlara göre yetiştirme süreci olan eğitim (Fidan,2012:4) hayat boyu devam eden uzun bir süreçtir. Planlı ve düzenli bir sistem içinde devam eden eğitime sürecine öngörülenden fazla ara verilmesi, uzun süre eğitim faaliyetlerinin yapılamaması gibi durumlar eğitim sürecini olumsuz etkilemektedir. Deprem, salgın hastalıklar, terör ve toplumsal olaylar vb. sebeplerden ötürü yüz yüze eğitime ara verilmesi gereken durumlarda eğitim faaliyetlerinin planlanması ve icrası son derece önemlidir. Ani gelişen bu tip durumlarda eğitim faaliyetlerinin alternatif bir yöntemi olması eğitimin kaldığı yerden devam etmesini sağlayacaktır.

Türkiye'de eğitim altyapısındaki çeşitli eksiklikler nedeniyle 1927 yılında mektupla öğretim yöntemiyle uzaktan eğitim süreci başlamıştır. Eğitimin fiziki problemleri çözülene kadar mektupla öğretim devam etmiştir (Arar, 1999: 26). Teknik alt yapının da güçlenmesiyle uzaktan eğitim faaliyetleri televizyon aracılığıyla yapılmaya başlanmıştır. 1951 de uzaktan eğitim faaliyetlerini herkese ulaştırabilmek amacıyla Öğretici Filmler Merkezi (ÖFM) oluşturulmuş ve uzaktan eğitim süreci bu merkez aracılığıyla yürütülmeye çalışılmıştır (Papi ve Büyükaslan, 2007: 3). Teknolojik gelişmelere paralel olarak da Türkiye'de televizyondan uzaktan eğitim Anadolu Üniversitesi'nin 1982 yılındaki televizyondan dersleri ile başlamıştır (Kunç ve Varol,1994:455).

Günümüzde ise teknılojinin hızla ilerlemesi ile eğitim kurumları uzaktan eğitim yapabilecek çeşitli donamım ve yazılımlar satın alarak uzaktan eğitim faaliyetlerini yürütmektedir. Anadolu Üniversitesi, Sakarya Üniversitesi, İstanbul Üniversitesi, Marmara Üniversitesi, Kocaeli Üniversitesi, İnönü Üniversitesi, Hoca Ahmet Yesevi Uluslararas1 Türk-Kazak Üniversitesi gibi birçok üniversitede uzaktan eğitim programları açılmış ve dersler uzaktan eğitim şeklinde interaktif ve sanal ortamlarda yapılabilmektedir. Üniversiteler bu faaliyetleri planlamak için uzaktan eğitim merkezleri kurmakta ve yüz yüze yapılan eğitimlerin bazılarını uzaktan eğitim faaliyetine dönüştürmektedir. Millî Eğitim Bakanlığı da dünyadaki teknolojik gelişmeleri yakından takip ederek Fatih Projesi, Eğitim Bilişim A $\breve{g}$ (EBA), öğrencilere tablet bilgisayar dağıtımı gibi farklı uygulamalarla eğitimde dijital uygulamaların alt yapısını oluşturmuştur. $\mathrm{Bu}$ uygulamalar eğitim faaliyetlerinin büyük bir kısmının gelecekte dijital ortamlarda gerçekleşeceğinin göstergesidir. EBA sitesinde okullarda okutulan her dersle ilgili konu anlatımlan, videolar, sorular yer almaktadır. Öğretmenler öğrencilerine bu site üzerinden ödevler verebilmekte, öğrencilerin akademik gelişimlerini takip edebilmektedirler. EBA üzerinden öğretmenler öğrencileri ile canlı dersler yapabilmektedir. Geçmiş yıllarda Türkiye'de yaşanan deprem gibi doğal afetlerde eğitim öğretimin kesintiye uğradığı dönemlerde Bakanlık tarafından öğrencilere uzaktan eğitim yoluyla eğitim desteği sağlanmıştır. Bunun en son örneği Elâzı̆̆g, Van ve Malatya depremlerinde görülmüsştür. Okulları tatil edilen öğrenciler eğitimlerini Milli Eğitim Bakanlığının kurmuş olduğu 
Eğitim Bilişim Ağı (EBA) sisteminden takip etmeye başlamıştır (EBA, 2020).Okulların tatil edildiği bu dönemde uzaktan eğitim öğrencilere fırsat eşitliği imkânı sağlamaktadır (Yalın, 2009). Uzaktan eğitim ile ilgili literatürde yapılan araştırmalar tarandığında bu konuda olumlu görüşlerin yanı sıra olumsuz görüşlerin de olduğu görülmektedir. Birişçi’nin (2013) öğrencilerin uzaktan eğitim uygulamaları ile öğrenci görüşlerini tespit ettiği araştırmasında neticesinde uzaktan eğitim uygulamasıyla ilgili olumsuz öğrenci görüşlerinin fazla olduğu görülmüştür. Arslan ve Şahin'in (2013) araştırmasında da etkileşim imkânının zayıflığından dolayı uzaktan eğitim yoluyla hizmet içi eğitim derslerinin yapılması hususunda öğretmenler olumsuz görüş beyan etmişlerdir. İnan'ın (2013) çalışmasında ise öğretim elemanları uzaktan eğitimin faydalı olduğu görüşünü belirtmişlerdir. Günümüzde uzaktan eğitim faaliyetlerinin yürütüldügüü bir portal olan ve yaygın bir şekilde kullanılan EBA sistemini kullanan öğrencilerin çoğunluğu EBA sitesinin ödev, ders çalışma, konu tekrarı, derse ön hazırlık yapma ve sınavlara çalışma gibi hususlarda çok faydalı olduğunu ifade etmiştir (Tüysüz ve Çümen,2016:292). EBA sisteminin öğrencilere katkılar sağladığı çeşitli araştırmacılar tarafından dile getirilmiştir (Aktay ve Keskin, Aydınözü, Sözcü ve Akbaş 2016). Üç ili kapsayan bu uygulama günümüzde Covid-19 Pandemi süreci ile tüm Türkiye'de hatta dünyadaki ülkelerin birçoğunda uygulanmak zorunda kalmıştır. Dünya Sağlık Örgütü tarafindan pandemi ilan edildiği için okullar tatil edilmiştir. Eğitime ara verilmiş ve eğitim uzaktan eğitim şeklinde gerçekleştirilmeye çalışılmıştır. Burada önemli olan bu sürecin nasıl işlediğini takip etmek ve uzaktan eğitim sürecinde öğrencilerin, öğretmenlerin yaşadığı sorunların neler olduğunu ortaya çıkarmaktır. Uzaktan eğitim sürecinde yaşanan aksaklıkların neler olduğunun tespit edilmesi ve hızlı bir şekilde çözüm önerileri geliştirilmesi sürecin sağlıklı bir şekilde ilerlemesine yardımcı olacaktır. Uzaktan eğitim sürecinde yaşanan teknik aksaklıkların, öğretmenden ve öğrenciden kaynaklanan sorunların neler olduğunu belirlemek ve bu doğrultuda çözümler geliştirmek uzaktan eğitim altyapısının iyileştirilmesine katkı sağlayacaktır. Bu amaçla Covid-19 pandemi uzaktan eğitim sürecinde Türkçe eğitiminin durumunu tespit etmek için bu çalışma yürütülmüş̧ür. $\mathrm{Bu}$ tür ulusal ya da uluslararası felaketlerin yaşanması durumunda Türkiye'de uzaktan eğitim sürecinde Türkçe eğitimi özelinde yaşanan aksaklıkları ortaya çıarmanın gelecekte planlanacak uzaktan eğitim faaliyetlerine yön vereceği ve katkı sağlayacağı düşünülmektedir. Bu süreçte tespit edilen eksiklikler telafi eğitimlerine yön verecektir. Planlanacak telafi eğitimleri araştırma neticesinde geliştirilen çözüm önerileri doğrultusunda daha etkin ve amacına uygun yürütülebilecektir. Okulların tatil edildiği bu dönemde uzaktan eğitimin temel amacı uzaktan eğitim etkinliklerinin hedef kitlesinin tamamına hitap edebilmek, eğitim faaliyetinden tüm öğrencileri yararlandırabilmektir. Araştırmanın amacı doğrultusunda Türkçe öğretmenlerinin Covid-19 pandemi uzaktan eğitim sürecinde Türkçe eğitiminin durumunu tespit etmek amacıyla görüşleri alınmıştır. Bu amaç doğrultusunda araştırmaya katılan Türkçe öğretmenlerine aşağıdaki sorular yöneltilmiştir.

1.Covid-19 pandemi dönemi uzaktan eğitim sürecinde Türkçe eğitiminin durumu nedir/neler yaptınız kısaca değerlendiriniz?

2. Covid-19 pandemi dönemi uzaktan eğitim sürecinde yaşadığınız sorunlar ve çözüm önerileriniz nelerdir?

3.Öğrencilerin uzaktan eğitim sürecinde, canlı derslerde Türkçe derslerine katılım düzeyleri nasıldır, okuldaki dersler ile kıyaslayınız. Bunu arttırabilmek için neler yapılabilir?

4.Uzaktan eğitim süreci öğrencilerin Türkçe dersine olan ilgilerini ne düzeyde etkiledi? Sizce süreç öğrencilerin akademik başarılarını nasıl etkiledi?

5. Covid-19 pandemi uzaktan eğitim sürecinde kullandığınız eğitim portalı ya da programı ile ilgili görüşlerinizi açılayınız. Sizce daha nitelikli bir sistem olabilir miydi/nasıl olabilirdi?

6. Covid-19 pandemiUzaktan eğitim sürecinde velilerden dersinizle alakalı olumlu ya da olumsuz dönütler aldınız mı açıklayınız? 
7. Bundan sonraki süreç sizce nasıl ilerler, dersler uzaktan eğitimle yapılabilir mi? İlerleyen yıllarda öğretmenlerin durumuna nasıl bakıyorsunuz? Türkçe ders kitapları uzaktan eğitim sürecine göre yeniden ele alınmalı mıdır? İlerleyen süreçte kitapların belirli bir bölümünde öğrencilerin sanal ödevleri veya görevleri vb. olabilir mi?

\section{Yöntem}

$\mathrm{Bu}$ araştırma nitel desenli bir durum çalışması şeklinde yürütülmüştür. Durum çalışmalarının en belirgin özelliği farklı yöntemlerle irdelenememe ihtimali olan detay bilgileri titizlikle inceleme olanağı sunmasıdır (Punch, 2014). Covid 19 pandemi sürecinde Türkçe eğitiminin durumu detaylıca araştırılmak istendiğinden nitel durum çalışması tercih edilmiştir (Yıldırım ve Şimşek, 2018). Araştırmada Türkçe öğretmenlerinin uzaktan eğitim süreci hakkında görüşlerine başvurulmuş ve süreç tüm yönleriyle kapsamlı bir şekilde değerlendirilmeye çalışılmıştır.

\section{Çalışma Grubu}

$\mathrm{Bu}$ araştırma gönüllü Türkçe öğretmenlerinden oluşan çalışma grubu yöntemi ile gerçekleştirilmiştir. Araştırmacinın Türkçe öğretmeni olarak görev yaptığı ildeki Türkçe öğretmenleri kolay erişilebilirlik ilkeleri doğrultusunda çalışma gurubu yöntemine dâhil edilmiştir. Çalışma kolay erişilebilen durum örneklemesi şeklinde yürütülmüştür. (Yıldırım ve Şimşek, 2018). Araştırmanın çalışma grubu Antalya merkez ilçelerinde görev yapan araştırmaya gönüllü olarak katılan 30 Türkçe öğretmeninden oluşmuştur.

\section{Verilerin Toplanması}

Araştırmanın verileri yarı yapılandırılmış görüşme formu ile elde edilmiştir. Görüşme formu 4 alan uzmanına danışılarak oluşturulmuştur. Alan uzmanları görüşme sorularının anlaşılırlığının sınanması için araştırmaya başlamadan önce birkaç Türkçe öğretmeniyle görüşmeler yapuılmasını tavsiye etmiştir. Alan uzmanlarının yönlendirmeleri neticesinde pilot görüşmeler yapılmıştır. Görüşmeler neticesinde yarı yapılandırılmış görüşme formunun araştırmaya katılacak kişiler tarafından anlaşılabilir olduğu kanaatine varılmıştır. Görüşme formu hazırlanırken soruların uzaktan eğitimi sürecinde Türkçe eğitiminin durumunu ve Türkçe öğretmenlerinin karşılaştığı sorunları tam olarak ortaya çıkarabilecek şekilde olmasına dikkat edilmiştir. Araştırmaya katılan Türkçe öğretmenlerine araştırma hakkında bilgi verilmiştir. Covid19 pandemi süreci nedeniyle katılımcılarla yüz yüze görüşme gerçekleştirilememiştir. Katılımcılara araştırma soruları mail yoluyla ulaştırılmıştır. Katılımcıların yanıtları da mail yoluyla alınmıştır. Katılımcıların yanıtları alındıktan sonra katılımcılarla telefon aracılığıyla katılımcılarla irtibat kurulmuş ve yanıtlarına ilaveler yapmak isteyip istemedikleri sorulmuştur. İlave yapmak isteyen katılımcıların yanıtları araştırma verilerine dâhil edilmiştir.

\section{Verilerin Analizi}

Araştırmanın verileri analiz edilirken içerik analizi ile betimsel analiz yöntemleri kullanılmıştır. Araştırmaya katılan Türkçe öğretmenlerinin yarı yapılandırılmış görüşme formuna vermiş olduğu yanıtlar 7 kategoriye ayrılarak değerlendirilmiştir. İçerik analizleri doğrultusunda araştırmanın verileriyle uzaktan eğitim sürecinde Türkçe eğitiminin durumuyla ilgili birtakım ilişki ve bağlantılar oluşturulmaya çalışılmıştır (Yıldırım ve Şimşek, 2018). Araştırmaya katılan Türkçe öğretmenlerinin görüşleri doğrudan alıntılar ile araştırmanın bulgular bölümünde sunulmuştur. Böylelikle araştırmanın güvenilirliğine katkı sunulmaya çalışılmıştır. Araştırmaya katılan Türkçe öğretmenleri Ö1,Ö2,Ö3... şeklinde kodlanarak gösterilmiş ve etik ilkelerine dikkat edilmiştir. Araştırmadan elde edilen veriler önce araştırmacı tarafından incelenmiş ardından da 2 alan uzmanı tarafından incelenmiştir. Alan uzmanlarının incelemeleri ile araştırmacının incelemeleri neticesinde araştırma verilerinin tutarlı düzeyde olduğu görülmüştür. Bu durumu ortaya koyarak araştırmanın güvenilirliğini tespit etmek için Görüş Birliği/ Görüş Birliği+ Görüş Ayrıllğ hesaplamas1 
kullanılmıştır (Miles ve Huberman 1994). Hesaplama neticesinde güvenilirlik oranı 0,93 olarak bulunmuştur.

\section{Etik Kurul}

Araştırma ile ilgili 02.06.2020 tarihinde Antalya İl Milli Eğitim Müdürlüğü Arge ve Etik Kurul birimine başvurularak araştırma için 08.06.2020 7575714 sayı ile gerekli onay alınmıştır. Araştırmaya katılan Türkçe öğretmenlerin kişisel bilgileri ile ilgili etik ilkelerine riayet edilmiş ve katılımcılar kodlanarak araştırmada belirtilmiştir.

\section{Bulgular}

Araştırmanın bulguları yarı yapılandırılmış görüşme formunda yer alan sorular doğrultusunda 7 kategoriye ayrılarak incelenmiştir. Oluşturulan kategoriler sırasıyla aşağıda sunulmuştur. Katılımcıların görüşlerinden doğrudan alıntılar yapılarak araştırma bulgularının güvenilirliği desteklenmiştir.

\section{Covid-19 Pandemi Uzaktan Eğitim Sürecinde Türkçe Eğitiminin Durumu Hakkındaki Görüşler}

Araştırmaya katılan Türkçe öğretmenlerine okulların tatil edildiği pandemi döneminde Türkçe derslerini nasıl işledikleri sorulmuştur. Öğretmenlerden alınan yanıtlar Tablo 1'de gösterilmiştir.

Tablo 1: Uzaktan Eğitim Sürecinde Ders İşlenişi

\begin{tabular}{ll}
\hline Uzaktan Eğitim Sürecinde Türkçe dersini nasıl işlediniz? Hangi uygulamayı kullandınız? & $\mathrm{N}$ \\
\hline Ders işlemedim. & 1 \\
\hline Sadece Zoom uygulamasını kullandım. & 4 \\
\hline Sadece EBA canlı ders uygulamasını kullandım & 6 \\
\hline Sadece benzer uygulamaları kullandım & 1 \\
\hline Zoom uygulamasını kullandım ve whatsapp ile ödevlendirmeler yaptım. & 6 \\
\hline EBA canlı ders uygulamasını kullandım ve Whatsapp ile ödevlendirmeler yapıp, iletişim kurdum. & 12 \\
\hline
\end{tabular}

Tablo 1 incelendiğinde 30 katılımcidan sadece 1 tanesi pandemi nedeniyle okulların tatil edildiği süreçte Türkçe dersi işlemediğini, Millî Eğitim Bakanlığı'nın uzaktan eğitimi televizyondan da yaptığını ifade etmiştir. 4 katılımcı Zoom isimli bir program ile Türkçe derslerini işlediğini beyan etmiştir.6 katılımcı EBA canlı ders uygulaması ile Türkçe derslerini yürütmeye çalıştı̆̆ını belirtmiştir.1 katılımcı ise benzer programlar kullanarak Türkçe derslerini işlediğini ifade etmiştir. Araştırmaya katılan 6 Türkçe öğretmeni ise Zoom programını kullanarak derslerini işlediğini ve whatsapp uygulaması ile de ödevlendirmelerini yaptığını beyan etmiştir. 12 Türkçe öğretmeni ise Türkçe derslerini eba canlı ders uygulaması ile yaptığını whatsapp uygulaması ile öğrencilere ödevlendirmeler yapıp, onlarla iletişim kurduğunu ifade etmiştir. Araştırmaya katılan Türkçe öğretmenlerinin \%87'sinin okulların tatil edildiği pandemi döneminde Türkçe derslerini işlemeye çalıştı̆̆ı, öğrencilerin eğitimlerini devam ettirme noktasında gayretli ve istekli oldukları görülmektedir.

Araştırmaya katılan Türkçe öğretmenlerinin pandemi uzaktan eğitim sürecinde Türkçe eğitiminin durumu hakkındaki görüşleri değerlendirildiğinde öğretmenlerin öğrencileri bu süreçte yalnız bırakmadıkları görülmüştür. Millî Eğitim Bakanlığı'nın bu süreçte canlı ders yapma ya da çeşitli uygulamalar ile derslerin işlenmesi konusunda öğretmenleri zorunlu tutmamıştır. $\mathrm{Bu}$ süreç gönüllü öğretmenler ile sürdürülmüştür. Türkçe öğretmenlerinin zorunlu olmamalarına rağmen uzaktan eğitim yoluyla derslerini işlemeye devam etmesi Türkçe eğitimi adına sevindiricidir. Katılımcılar Eba TV ile başlayan uzaktan eğitim sürecinin kendileri tarafindan Zoom, gibi uygulamalarla canlı dersler şeklinde devam ettiğini, ilerleyen süreçte bakanlığın EBA canlı ders uygulamasını hayata geçirmesiyle derslere buradan devam ettiklerini ifade etmişlerdir. Araştırmaya 
katılan Türkçe öğretmenleri whatsapp uygulaması gibi iletişim kanalları ile öğrencilere ödevlendirmeler yaptıklarını ifade etmiştir. Katılımcıların sorulara verdiği yanıtlar doğrudan alıntılar yapılarak aşağıda sunulmuştur.

"Öğrencilerle EBA ve farklı medya ortamları üzerinden canlı dersler yapıldl, Öğrencilerin anlamadı̆̆ sorular çözüldü. Whatsapp üzerinden ögrencilere sorular gönderildi. Velilerle gerek mesaj gerek konuşarak öğrencilerin durumları takip edildi." (Ö.1)

"Uzaktan ĕgitim sürecinde yaptığımız uzaktan canlı derslerden edindiğimiz intiba katılan ögrencilerin ilgisi ve verdikleri cevaplar ve ögrenmeye istekli olmalart sevindiricidir fakat katılım yüzdesinin \% 35 veya 40 civarında olması ailelerin çocukların yeterince motive etmediklerini düşündürüyor." (Ö.3)

"Türkçe eğitimi pandemi sürecinde diğer saylsal derslere nazaran daha avantajlı bir durumdaydl. Dolaslyla derslerde normal sürecin içinde yapabildiğimiz etkinlikleri de yapma imkânımız oldu. Gerek konu tekrarı gerekse soru çözme vb. uygulamaları yapma hususunda bir zorluk yaşamadım diyebilirim." (Ö.9)

"İşleyemediğimiz konuları anlattık, etkinlik ve soru çözümü yaptık. EBA canlı dersler ile ögrencilerimiz ile bir araya gelmeye çalıştık.” (Ö.14)

"Sözel ders olduğu için çevrimiçi derslerde ve tekrarlarda sorun yaşanmadl. EBA uygulamasında çoğu zaman sorunlar yaşasak da ögrencilerime ders anlatmaya çalıştım." (Ö.18)

"Türkçe eğitimi uzaktan çok zor oldu bence. Çünkü ögrrencilerin bir kssmı internet erişimine ve bilgisayara sahip değildi. Ancak elimden geldiğince katılan öğrencilere çözümlü örnekler ve konu anlatımları ile canlı dersleri kolaylaştırmaya çalıştım. EBA ve EBA TV de bu konuda bizlere büyük destek oldu." (Ö.21)

"Ülkemizin ve dünyanın virüsle mücadelesi kapsamında Türkiye hem sağllk hem eğitim alanında süreci en iyi şekilde yönetmek için elinden geleni yapmıştır. Ancak maalesef hiç bir şey bu yaş dönemi çocuklar için yüz yüze olan eğitimin yerini tutamaz. Öğrencilerin okullarda haftada en az 5 ders saati Türkçe dersi gördügünü göz önüne alırsak EBA TV den 2 kez 20 şer dakikalık yayın tatbikî yeterli olmamıştır. İlk zamanlar hevesli olsalar da çoğu öğrenci anlayamıyoruz, bağlanamıyoruz diyerek son zamanlarda izlemeyi de birakmıştır.” (Ö.23)

"Uzaktan eğitim süreci kısa bir zaman içinde hayata geçirildiği için başlarda uygulamadan kaynakl aksakliklar vardl. Zamanla düzeltildi, Şu an da kendi adıma konuşursam sorunsuz bir şekilde EBA canlı derse bağlanabiliyorum. Öğrencilerden de aynı şekilde bağlanma konusuyla ilgili şikâyetler nerdeyse yok denecek kadar azaldr. Illk başta öğrenciler yeni bir uygulama olduğu için heveslilerdi. Çoğu bă̆lanmaya çalışıyordu, derse katılmaya çalışlyordu. Fakat çoğunun evinde uygulamayı kaldıracak bilgisayar ya da telefonu olmadı̆̆ için ya da sınırsız internet imkânı olmadığ için katılımlar giderek azaldı. Düzenli olarak katılım sağlayan ögrenci sayısı azdl. Fakat

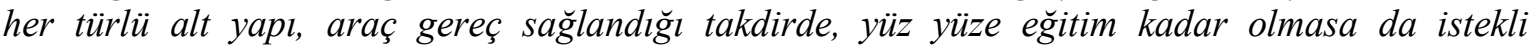
öğrenciler için bu süreçte verimli olduğunu düşünüyorum. Derslerden sonra derse katılan öğrencilerimi arayıp verim alıp alamadıkların sorduğumda EBA TV de ve ya eba internet sitesinde etkinlikleri yaparken kafalarına takılan kisımları canlı derslerde sorduklarını ve anladıklarını bu yüzden canlı derslerin faydalı olduğunu söylüyorlardı." (Ö.24)

"Türkçe dersi hem öğretmen hem de ögrenci açısından aktif olunması gereken bir derstir. Ögrenciler ögrretmenin jest-mimik ve hareketlerle gösterdiği dili, derse etkin katılarak edinirler. Uzaktan ĕ̆itim sürecinde öğretmen-öğrenci, ögrenci-öğrenci etkileşimi sağlanamaması dersi düz anlatıma dönüş̧ürdü. Bu da dersin etkililiğini azalttı. EBA canlı derslere kattlım bilgisayar ve internet yetersizliğinden istediğimiz seviyede olmadı maalesef. Dersine girdiğim sinıfların yarısı ancak katılabildi canlı derslere." (Ö.26)

Turkish Studies, 15(4) 
"Uzaktan eğitim hepimiz için ani, zor ve yeni bir süreç oldu. Bu sürece bazı eksiklikler olsa da uyum sağladık. Türkçe eğitiminde, yıl içindeki müfredata uygun okuma parçalarıyla ve alıştırmalarla pekiş̧irmeye çalış̧ık, canlı derslere öğrenci katılımında eksiklikler olduğundan, ev çalışmalarının etkili olmadı̆̆ını düşünüyorum. Umarım eksiklikler giderilir. Uzaktan eğitim ilerleyen süreçte devam edecek gibi görünüyor. "(Ö.28)

"Türkçe ögretimi genelde soyut kavram ve ilkeleri içeren bir derstir. Dolaylsılyla uzaktan eğitim sürecinde özellikle 8. sinıflar için LGS kapsamında tekrarlar ve soru çözümü yaptım. Bunun için ise genellikle ders kitabı ve farklı kaynaklardan sorular ekrana yansitılarak ögrencilerle soru üzerinden genel tekrarlar yapılmış ve konular pekişstirilmiştir. Alt şubeler için ise 13 Mart 2020 tarihinden sonra var olan kazanımlar, ders kitabı üzerinden ögrencilere sunmaya çalıştım. Ayrıca EBA üzerinden her şube için konu anlatımı sunuları, tarama testleri, beceri temelli testler ve bunların ne derece yapılıp yapılmadı̆̆ ödevlerin bitiş tarihinden sonra kontrol edilerek bir sonraki derste ögrencilere gerekli dönüt ve düzeltmeler vermeye çalıştım. Bilgisayarı ya da interneti olmayan öğreniciler maalesef bazı uygulamalardan mahrum kaldı. "(Ö.30)

\section{Covid-19 Pandemi Uzaktan Eğitim Sürecinde Türkçe Eğitimi İle İlgili Yaşanılan Sorunlar ve Çözüm Önerileri Hakkındaki Görüşler}

Araştırmaya katılan Türkçe öğretmenlerine uzaktan eğitim sürecinde Türkçe eğitimiyle ilgili yaşadıkları sorunları ifade etmeleri istenmiştir. Katılımcılar öğrencilerin bir kısmında bilgisayar, tablet gibi cihazların olmayışından canlı derslere katılamadıklarını belirttiler. Öğrencilerin bir kısmında da internet erişimi olmayışı canlı derslere katılma konusunda sorun olarak belirtilmiştir. Araştırmaya katılan Türkçe öğretmenleri uzaktan eğitim süreci başladığında kendilerinin çözüm olarak farklı video ders uygulamalarını kullandığını ancak bakanlığın başlattığı eba canlı ders uygulamasından sonra bu uygulamayla canlı derslere devam ettiklerini belirtmiştir. EBA canlı ders uygulamasının bağlantı sorunları olması, zaman sınırlaması olması gibi çeşitli aksaklıklarının olduğunu ifade eden katılımcılar bu olumsuzlukların zaman içinde azaldığını ifade etmiştir. Katılımcılar EBA canlı ders uygulamasının ve EBA eğitim ağının Türkçe ders kitaplarıyla entegre olmasını, sistemin zenginleştirilmesi gerektiğini dile getirmiştir. Türkçe öğretmenleri konu testleri, deneme sınavları ve çalışma yapraklarının sisteme dâhil edilmesinin faydalı olacağını dile getirmişlerdir. Uzaktan eğitim sürecinin öğrenciler ve öğretmenler tarafından katılımının gönüllü olması Türkçe eğitimi adına bir bütünlüğün oluşmamasına yol açmıştır. Araştırmaya katılan öğretmenler ayrıca velilerin bir kısmının bu süreçte ilgisiz olduğunu, öğrencileri bilgisayar başındayken takip etmediklerini, özellikle her ikisi de çalışan velilerin çocuklarının süreç için kontrolsüz kaldığııı ifade etmiştir. Bu sürecin bazı öğrencilerde ekran bağımlılı̆̆ 1 oluşmasına neden olduğunu ifade eden öğretmenler velilerin de bu konuda eğitilmesi gerektiğini belirtmiştir. Bazı öğretmenler özellikle canlı dersler esnasında öğrencilerin kontrolünü sağlamak, öğrencileri takip edebilmenin zor olduğunu belirtmiştir. Araştırmaya katılan Türkçe öğretmenlerinin uzaktan eğtim sürecinde karşılaştıkları sorunlar Tablo 2'de sunulmuştur.

Tablo 2: Uzaktan Eğitim Sürecinde Karşıllaş1lan Sorunlar

\begin{tabular}{lc}
\hline Öğrencilerin bilgisayar, tablet gibi cihazlarının olmayışı & 8 \\
\hline Öğrencilerin bir kısmında internet erişimi olmayışı & 10 \\
\hline EBA canlı ders uygulamasının bağlantı sorunları ve zaman sınırlaması olması & 28 \\
\hline EBA canlı ders uygulamasının ve EBA’nın Türkçe ders kitaplarıyla entegre olmaması & 25 \\
\hline EBA canlı ders uygulamasının zenginleștirilmesi & 22 \\
\hline EBA canlı ders uygulamasının materyal eksikliği & 7 \\
\hline Katılımın zorunlu olmayışı & 14 \\
\hline Velilerin ve öğrencilerin uzaktan eğitim sürecine ilgisizliği & 9 \\
\hline Öğrencilerin uzaktan eğitim süresince takip edilemeyişi/kontrolsüz kalmaları & 13 \\
\hline
\end{tabular}


Araştırmaya katılan Türkçe öğretmenlerine uzakta eğitim sürecinde karşılaştıkları sorunları belirtmeleri istenmiştir. Katılımcılardan 28'i EBA canlı ders uygulamasının bağlantı sorunları ve zaman sınırlaması olmasının uzaktan eğitim sürecinde karşılaştığı sorunların başında belirtmiştir. 25 Türkçe öğretmeni EBA canlı ders uygulamasının ve EBA'nın Türkçe ders kitaplarıyla entegre olmamasını uzaktan eğitim sürecinde karşılaştığı sorunlar arasında olduğunu ifade etmiştir. 22 katılımcı EBA canlı ders uygulamasının zenginleştirilmesi gerektiğini ifade etmiştir. Araştırmaya katılan 14 Türkçe ögrretmeni canlı ders uygulamasına katılımın zorunlu olmayışını bir sorun olarak ifade etmiştir. 13 katılımcı öğrencilerin uzaktan eğitim süresince takip edilemeyişi/kontrolsüz kalmalarının bir sorun olduğunu belirtmiştir. Öğrenciler bu süreçte kontrolsüz kalmalarının ekran bağımlılığı gibi olumsuz alışkanlıklar edinmesine yol açtığı ifade edilmiştir. 10 katılımcı öğrencilerin bir kısmında internet erișiminin olmayıșının uzaktan eğitim sürecini olumsuz etkilediğini ifade etmiştir. Araştırmaya katılan Türkçe öğretmenlerinin yanıtlarından doğrudan alıntılar aşağıda verilmiştir.

"Sürecin başında canlı derse bağlanamama, hata mesajlarl, cep telefonu ile EBA'ya giriş yapamama gibi sorunlarla karşılaştım. Sonrasinda bu hatalar çoğunlukla giderildi. Ancak hala canlı derse bağlanma konusunda internet bağlantısı veya sistemsel sorunlardan kaynakl olabileceğini düşündü̈̆üm sebeplerden dolayı bazı canlı derslere bağlanmakta sorunlar yaşadım. EBA ve canlı ders uygulaması gerçekten bu süreçte eğitime sunulmuş bir ilaç gibiydi. En azından bu platformda ögrencilerle bir araya gelebildik ve her ne kadar yüz yüze eğitim kadar etkili olmasa da konulardan ve iletişimden öğrencileri eksik etmemiş olduk. Ancak burada düzeltilmesi gereken tek bir durum var: Canlı ders esnasından ekran paylaşımının olmasl gayet yerinde ki e-kitap, test vs. paylaşımı yapıp çok faydasını gördüm. Ancak aynı şekilde ekran paylaşımını seçtikten sonra EBA ana sayfayı da canlı derste görüntü olarak paylaşabilmeyi isterdim. Bu şekilde oradaki konu anlatımları, ünite testleri, etkileşimli uygulamaları öğrencilerle birlikte yapabilirdik. Aynı şekilde EBA'da ödev verdiğim etkinliklerin tekrarını yapabilirdim." (Ö.2)

"Evlerinde internet, bilgisayar olmayan ögrencilerimiz derse katılamadl. Internet bağlantı hızından dolayı dersten düşmeler yaşadım. Canlı ders bağlantılarında Türkiye genelindeki yoğunluklardan dolay donmalar ve kopmalar oldu." (Ö.3)

“ Bu süreçte öncelikle teknik sorunlar, bağlanmada kimi öğrencilerin başarısız olması, ikinci olarak eğitimin yüz yüze göz göze olmamasından kaynaklı bir noksanlık, bir burukluk olması bizleri üzmüştür. Katılımın artırılması için velilerle irtibata geçilmesi, teşvik edici önlemler alınması düşünülebilir." (Ö.7)

"Teknik donanımı ve interneti olmayan bazı istekli ögrenciler düzenli faydalanamadı. EBA bazen içerik olarak yetersiz kaldı. Isslenen konularla ilgili geri dönüt sağlamak amacıyla konu testleri, deneme sinavları, çalışma yaprakları sisteme dâhil edilebilir." (Ö.10)

"Uzaktan eğitim sürecinde yaşadı̆̆ımız zorluluklar canlı derslere olan ilginin az olması. Tabi bunu öğrencinin gözüyle de bakmamı daha faydalı olacaktır. Kimi öğrencilerin gerekli teknik araç hususunda gerekli donanıma sahip olmamasl, interneti olmayan ailelerin mevcut olmamasl, ailelerin gerekli hassasiyeti göstermemesi sayılabilir." (Ö.15)

"Yaşanılan aksaklıklar: Öğrencilerin ekranın karsı tarafinda ne yaptığını görememek, onlarla göz teması kuramamak, dersin hangi kısmında dersten koptuğunu anlayamamak, hepsinde uygulamayı kaldıracak telefon, bilgisayar ya da tablet olmamast, eba canlı derslerde internetin ücretli olmasl, bağlantı sorunlarını, öğretmenlerin çok fazla program ya da uygulama bilgisi olmadan birden böyle bir süreç içine girmeleri, çok fazla ekran karsisında kalmanın insan vücuduna biyolojik ve psikolojik zararları, ögrencilerin evlerinde hemen çıktı alacak bir yazıcı olmaması ve bu yüzden verilen etkinlikleri hep ekran karsisinda yapmak zorunda olmaları, EBA canlı ders uygulamasinın her hafta güncellenmesinden dolayı haftalık bir program oluşturulamadığ için öğrencilerin hangi gün hangi saat derse gireceklerini çok önceden bilmemeleri. Çözüm önerileri olarak; ögrrencilere 
eba canlı ders kullanımı için ücretsiz internet imkânı, gerekli araç gereç, eba canlı ders için sağlam bir ăg alt yapı sağlanmalı diye düşünüyorum." (Ö.19)

"Canlı derslerde görevimin olduğu sinıflarda katılım düzeyi \%15 - \% 30 aralı̆̆ında olup okuldaki derslerle kıyaslanamaz düzeydedir. Bunu arttırabilmek için imkânı olmayan ögrencilerin internete ve bilgisayara/tablete ulaşması sağlanabilir. Örgün eğitimdeki gibi sürecin devamlılı̆̆ını sağlamak amacıyla çeşitli ölçme ve değerlendirme metotlarından faydalanılmalıdır." (Ö.23)

"Maalesef ebaya giriş yapamayan ögrrenci saylsı oldukça fazla idi. Şifre bilmeyen, unutan, bazıları telefondan bazıları bilgisayardan bağlanmakta sorun yaşadılar. Bu kadar uzun bir sürede bir kez bile arayıp çocuğu için herhangi bir bilgi almayan velilerim oldu. Bazen tam tersi. Mesajla ya da konuşarak defalarca anlattığımı bir sorun için tekrar tekrar aradılar. Canlı derslerde ise Türkçe dersi olmasl sebebi ile kalem kullanamamak, telefondan isteğimiz her belgeyi gönderememek bizim için sorun oluşturdu. Öğrencilerimle sorunsuz bir ders işlemek için kendi çocuklarımı sürekli susturmaya çalışmak ya da çocukların sokağa çıtkma yasă̆ı olduğu halde sirf ögrencilerle sessiz ortamda ders işleyebilmek için bir yerlere bırakma çabası ya da eve birilerini çağırma çabası benim için oldukça büyük bir sorundu." (Ö.25)

"Uzaktan eğitimin zorunlu olmaması nedeniyle bazı sinıflarda katılım az olmuştur. Beklediğim veli desteğini bazı sınıflardan alamadım. Öğrenciden geri dönüt almak çok zor oldu. EBA TV gibi her okulun kendi ögrencisine yönelik ders videoları hazırlaması, haftanın belirli günleri gerekli tedbirler alınarak ögrencilerin yüz yüze eğitim alması să̆lanmalıdır. Bu süreçte veli eğitiminin ne kadar önemli olduğu görülmüştür. Veli, öğrencisinin eğitim ögretimi ile bu kadar uzun süre yalnız başına ilk defa kalınca ne yapacağını şaşırmış, bazıları biz ögretmenlerden yardım almayı tercih ederken, bazıları öğrencilerini kendi başına bırakmıştır. Yani öğrenci ne yapacağına kendi karar vermiştir. Bu süreçte Bakanlığımı çocukların eğitimi için haftalık çalışma planları, EBA üzerinden etkinlikler ve aile ile birlikte izleyebilecekleri film günleri bile oluşturmuştur." (Ö.27)

"Uzaktan eğitimde internet ăğ gibi sebeplerden dolayı derse katılamayanların olması diğer ögrencileri "İstersem katılırım" düşüncesine sevk etti, Derse katılım bazı sintflarda 3-5 ögrenciye kadar düştü. Derse girişte EBA ya bağlanırken teknik sorunlarla karşılaşıldı. Ders esnasında ögrencileri kontrol edebilmek bir hayli güçtü ve dersi sabote eden ögrenciler de vardl. Bu da süreci olumsuz etkiledi. Çözüm olarak ise derse katılan ögrencilerin isimleri not edildi. Bu bazı sınıflarda uzaktan eğitime katılımı artırdı. Ders esnasında ses çıkarma, ekranı karalama gibi dersin akışını bozan öğrencilerin yetkileri kisitlandirılarak ve gerektiğinde kisitlama kaldırılarak ders işlenişi sağlandl." (Ö.29)

\section{Öğrencilerin Uzaktan Eğitim Sürecinde, Canlı Derslerde Türkçe Derslerine Katılım Düzeyleri ile İlgili Görüşler}

Araştırmaya katılan Türkçe öğretmenlerine uzaktan eğitim sürecinde öğrencilerin derslere katılım düzeyleri sorulmuş ve bunun okuldaki derslerle kıyaslanması istenmiştir. Ayrıca öğrencilerin uzaktan eğitim derslerine katılım düzeylerini arttırmak için neler yapılabileceği sorulmuştur. Öğretmenler, uzaktan eğitim derslerine belirli öğrencilerin katıldığını ifade etmiştir. Derslere katılımın zorunlu olmadığı anlaşılınca önceden derse katılan öğrencilerin de katılımlarının azaldığını belirtmiştir. Bilgisayar ve bağlantı eksikliği nedeniyle canlı derslere katılım sağlayamayan öğrencilerin çokluğu katılan öğrencileri de olumsuz etkilemiştir. Araştırmaya katılan Türkçe öğretmenleri uzaktan eğitimde öğrencilerin derse katılım düzeylerini arttırabilmek için veli takibinin önemli olduğunu ve ayrıca bir değerlendirme sistemin olmasının faydalı olabileceğini ifade etmiştir. Uzaktan eğitime katılan öğrencilere puan verilebileceğini belki de öğrenci karnesinde bununla ilgili bir ibarenin olmasının etkili olabileceğini belirtmişlerdir. Öğretmenler ayrıca bilgisayar ya interneti olmayan öğrencilere tablet dağıtılmasının ve internet erişimi sağlanmasının uzaktan eğitim derslerine katılımı arttırıp firsat eşitliği sağlayabileceğini ifade etmiştir. Türkçe öğretmenlerinin yanıtlarından doğrudan alıntılar aşağıda sunulmuştur. 
“Derse katılım düzeyleri düşüktü. Öğrenci katılımı çok azdı. Motivasyonları çok düşüktü. Watsapp gruplarına gereken konuşmaları yaptım ama pek değişmedi. Çoğunlukla aynı öğrenciler canlı derslere katılım sağladı." (Ö.4)

"Katılım sınıf durumuna göre değişiklik gösterdi. Her öğrencide canlı derslere katılımı sağlayacak gerekli araç ve internet olmadığından derslere katılımda sorunlar oldu. Mecburi olmaması bazı velilerin evde olmamalarından dolayı ögrencilerin bazıları derslere katılmadı. Fırsat eşitliği olmadı bence her öğrenci canlı derslere katılamadiğ için canlı derslerin yapılmaması daha sağllklı olabilirdi. Ya da her öğrencinin bir şekilde katılması sağlanmallydl.” (Ö.5)

"Canlı derslerin başladı̆̆ ilk haftalarda sınıf mevcutlarının ortalama 2/3 sinin derslere aktif katıldiğı, ancak devamında derslere katılım oranlarında azalma olduğunu tespit ettim. Öğrencilere bu durumu sorduğumda diğer derslerde de aynı şekilde katılımın bu kadar olduğunu belittiler. Katılımı artırabilmek için devamlılığın zorunlu olduğu, bunun sistemde kayıt edildiği ve dönem sonu karnede EBA katılım puanının yer alacă̆ bildirilebilir ki böyle bir değerlendirme alanı da süreç içerisinde karnelerde yer alacaktır diye düşünüyorum. Ya da derse katılımın onların faydasına olduğu bilinci ögrencilere ve aynı zamanda velilere anlatılmalıdır. "(Ö.8)

"Katılım düzeyleri imkânlar dâhilinde iyiydi sadece tüm ögrencilerin bundan yararlanamaması kötüydü. İlk başladı̆̆ımızda gayet heveslilerdi fakat özellikle bayramdan sonraki dönemde katılım çok düşı̈̈. Okuldaki derslerle klyaslandı̆ğnda tabiki yüz yüze eğitim kadar etkili değildi bence dersler. Tüm ögrenciler için katılım zorunlu olmalıydı ve imkânı olmayan öğrencilere internet erişimi sağlanabilir. Öğrencilere puanlama verilebilir derslere katılım oranlarına göre.” (Ö.11)

"Derslere katılım \%50 civarında oldu. Tabi ki ailelerin biraz daha işin içine girip desteklemeleri gerekirdi bir başka neden ise her ögrencinin evinde internetin olmayışı. İnternet yâda bilgisayar yoksunluğu katılımı olumsuz yönde etkiledi. Öğrencilere tablet dağıtılabilirdi diye düşünüyorum. Katılımı arttırmak için. Uzaktan eğitimde de bence not verilebilirdi. Katılan ögrencilere derse katılma ve ödevleri yapma durumuna göre puanlar verilebilir." (Ö.16)

"Derse katılım sınıftan sınıfa değişiyordu. Genel olarak istenilen düzeyde değildi. Her öğrencinin bu sürece katılamaması ve ögrrencilerin bu süreçten eşit faydalanamaması diğer öğrencilerinde olumsuz etkilenmesine neden oldu. Dersler okuldaki gibi zorunlu olmall ve mutlaka bu sürecin sonunda bir değerlendirme olmallydı. Öğrencilere tablet bilgisayar dağıttlabilir." (Ö.20)

"Öğrencilerimden canlı derslere ilk haftalarda ortalama 20 kişi katılmaktaydı ancak zaman ilerledikçe katılım oranı düştü. 5-6-7. Sinıflarda katılım 15 civarında kaldı, 8.sinıflarda ise 5-10 kişi katıldı. Okuldaki derslerimde her öğrenciye söz vermeye çalıştığım için katılım oranı çok daha yüksek olmaktaydı. Katılımın artması tüm ögrencilerin evde eşit imkânlara sahip olmastyla ve süreç sonunda işlenen derslerin değerlendirilmesinin de yapılacağını bilmeleriyle sağlanabilir." (Ö.22)

"En büyük sorun canl derslerdeki devamsızlıktı ve bu yüzden öğrenci çalışmalarının takibi zorlaştr. Yüz yüze eğitimde bütüncül bir yaklaşımla verdiğimiz bilgiyi değerlendirme, takip, geri dönüt gibi konularda daha az problem yaşıyorduk.” (Ö.26)

"Canlı derslere katılım çok azdı. Sinıflarım 30 - 32 kişilik. Ancak canlı derslerime katıllım en fazla 1015 kişiyle sınırlı kaldı. Hatta bazen 2 kişiyle ders yaptığım günler oldu. Katılan kişi sayısının az olmasının yanında derslerde sorularıma sadece belli kişiler cevap veriyordu. Diğerlerini de derse dâhil etmek amacıyla sorular sorduğumda nedense sesim az gitmiş. Duyamamışlar. Bilgisayarlarında problem vardı sanırım. Teknik alt yapı olarak yetersizlik vardı biraz. Teknik alt yapı düzeltili ve ögrencilere tablet, internet desteği sağlanırsa daha sağllkh olur diye düşünüyorum." (Ö.29) 


\section{Uzaktan Eğitim Sürecinin Öğrencilerin Türkçe Dersine Olan İlgileri ve Akademik Başarılarına Etkilerine Dair Görüşler}

Araştırmaya katılan Türkçe öğretmenlerine uzaktan eğitim sürecinin öğrencilerin Türkçe dersine olan ilgilerini ve akademik başarılarını ne düzeyde etkilediği sorulmuştur. Türkçe öğretmenleri sürecin çok ani geliştiğini canlı derslerin geç başlamasının öğrencileri olumsuz etkilediğini ifade etmiştir. Türkçe öğretmenleri EbaTv'den verilen derslerin çok az olması, Eba canlı ders uygulamasının bazı eksikliklerinin olması öğrencilerin derse karşı olan ilgilerini olumsuz etkilediğini ifade etmiştir. Araştırmaya katılan Türkçe öğretmenleri, derslere katılımların düzenli olmayışı, bazı öğrencilerle hiç canlı derslerin yapılamaması, ödevlendirme sisteminin olmayışı, ayrıca öğrencilerin derslere katılımlarının zorunlu olmayışının öğrencilerin ilgi ve akademik düzeylerini olumsuz etkilediğini ifade etmiştir. Türkçe öğretmenleri anne ve babaları çalışan öğrencilerin kontrolsüz kaldıklarından süreçten oldukça olumsuz etkilediğini belirtmiştir. Öğretmenlerin görüşlerinden doğrudan alıntılar aşağıda sunulmuştur.

"Böyle bir süreçte ögretmenleriyle iletişim kurabiliyor olmaları çocukları olumlu yönde etkiledi. Âmâ canlı ders sürecine geç başlanması, çocukların düzenli derse katılım sağlayamamaları, ayarlanan ders saatlerinin normal müfredatın çok altında sayıda olmast gibi sebeplerle normal müfredatın tamamlanması tam anlamıyla mümkün olmadı. Akademik başarıları da o yüzden olumsuz etkilendi. Türkçe başarısı olarak normal eğitimde daha alt seviyede olan öğrenciler Covid-19 sürecinde neredeyse tamamen dersten koptu." (Ö.2)

"Bizler girdiğimiz her sinıfin whatssapp gruplarından ödevler gönderdik. Takibini yaptık. Anlamadıkları soruları gönderdiler çözdük anlattık. Ancak sadece televizyondan takip ederek yeni bir konuyu öğrenmede sorun yaşadıklart için yeni bilgiler bir türlü oturmadl. Haliyle şu an 3 ay gibi bir konu eksikleri var." (Ö.6)

"Bu süreç ilgili öğrenci ve veliler için çok yararlı oldu. Anlamadıklarını daha rahat sorma imkânı buldular. Bireysel ögrenme daha çok oldu. Öğretmen ve ögrenci iletişimi olumlu şekilde gelişti. Hem okullarda aldlkları eğitimden uzak kalmaları hem de okulun sunmus olduğu imkânlarla arkadaşlarıyla kurdukları iletişimden ve sosyalleşme firsatlarından yoksun olmaları evlerde kisitlı hareket imkânıyla birleştiğinde durum ögrenciler için bunaltıcı bir hal almıştır. Millî Eğitim Bakanlığı'nın kısa sürede almış ve uygulamıs olduğu kararlar neticesinde üç farklı düzeyde ögrencilerin hizmetine sunulan EBA ara yüzü ve EBA TV kanalları üzerinden eğitim kesintisiz devam etmiştir. Böylece ögrrenciler yüz yüze eğitime verilen arada hem günlerini verimli şekilde geçirmiş hem de eğitimlerinden geri kalmamıştır. Bunun yanında akran etkileşiminden ve sosyalleşmeden uzak kalan ögrencilerin bu ihtiyaçlarını kısıtlı da olsa online ortamda gidermeleri sağlandl. Bu amaçla EBA Canlı dersler başlayana kadar online sohbet gruplarl açıldı süreç içerisinde öğrencilerin ihtiyaç duyduğu iletişim ve sosyalleşme ihtiyaçları giderildi yalnız hissetmelerinin önüne geçilmiştir." (Ö.13)

"Derse ilgileri katılım düzeyleri az olduğu için olumsuz etkilendi. Ders sayılarının yeterli olmaması vb durumlar sonucu akademik anlamda eksikler meydana geldi." (Ö.16)

"Akademik olarak aslında olumluydu, ögrrenciler merkeze ögrretmeni aldıkları için ve yanı başlarında onları etkileyen ve onların dikkatlerini dă̆ıtan örneğin bir arkadaş olmadı̆ derslerim verimli geçti. Bana kalırsa ders sayısı artırılmalıydı çünkü bir dersten bir sonraki derse en az 1 hafta geçtiği için bir önceki deste öğrenilen bilgilerin unutulmast söz konusu oldu." (Ö.21)

"Bu sürecin ögrrencilerin derse olan ilgi düzeylerini etkilediğini düşünmüyorum. Akademik başarıları ise sekteye uğramıştır. Ama telafi edilemeyecek çok büyük bir kayıp olduğunu düşünmüyorum." (Ö.23) 
"Bu süreci öğrenciler daha çok tatil süreci gibi değerlendirdiler. Canlı derslere katılım keyfi oldu, öğrendikleri bilgileri unuttular, düzenli çalışma alışkanlıkları aksadı, bu süreç akademik başarıyı olumsuz etkiledi." (Ö.27)

"İlgi azaldı. Öğrenciler zaten sınıfi Geçeceklerini biliyorlardı bu yüzden ciddiye almadılar. Bizim kanaat notumuz olmallydl." (Ö.29)

"Özellikle 5.6. ve 7. sinıf ögrrencilerinde derslerin eğlenceli geçtiği, aynı zamanda ögrenerek bu vakitlerini değerlendirdikleri izlenimi elde ettim. Okul ortamında sınıf içerisinde eğitim-öğretim süreçlerinde yer alan ögrenciler için uzaktan eğitim, siradanlıktan öte algılanarak derse daha ilgili olabileceklerini düşündürdü. Yüz yüze eğitiminle beraber ilerde bazı konular bilgisayar temelli öğretim yöntemi ile uzaktan eğitim şeklinde verilebilir. Akademik başarının etkisini ölçebilmek için ögrrencilere verilen eğitimi kapsayan bir test uygulanabilir. Bana göre uzaktan eğitim ile ögrencilerde daha az ama daha etkili ögrenmeler sağlanabilir. ”(Ö.30)

\section{Covid-19 Pandemi Uzaktan Eğitim Sürecinde Kullanılan Eğitim Portalı ya da Programı ile İlgili Görüssler}

Araştırmaya katılan Türkçe öğretmenlerine uzaktan eğitim sürecinde kullanılan eba canlı ders uygulaması ve eğitim portalı hakkındaki görüşleri sorulmuştur. Öğretmenler eba canlı ders uygulamasının teknik sorunlarının süreç içinde öğrencileri olumsuz etkilediğini, zamanla teknik sorunlar giderilmeye başlansa da tam anlamıyla sağlıklı bir ders işlenişi sağlanamadığından öğrencilerin katılım oranlarının azaldığını ifade etmiștir. Araştırmaya katılan Türkçe Öğretmenleri canlı derslerde zaman ve kota sınırı olmaması, istenilen her saatte eğitim portalının kullanılabilmesi gerektiğini ifade etmiştir. Türkçe öğretmenleri eğitim portalının alt yapısının güçlendirilmesi gerektiğini belirtmiştir. Araştırmaya katılan Türkçe öğretmenleri öğrencilerin istedikleri saatte izleyebilecekleri ders videolarının olması gerektiğini, her okulun kendi öğrencilerine yönelik eğitim içerikleri ve videoları hazırlayabilmesinin faydalı olabileceğini ve bu konuda da öğretmenlere dijital içerik geliştirme eğitimlerinin verilmesinin önemli olduğunu ifade etmiştir. Öğretmenlerin görüşleri doğrudan alıntılar yapılarak aşağıda sunulmuştur.

"Kullandiğımız programlar internet tabanlı programlardl. Herkesin erişimi zordu. EBA canlı derslerde ögrenciler kameralarını kapatabildikleri için öğretmeni dinleyip dinlendikleri anlaşılmıyordu. En büyük sorun ögrrencilerin bir üst sınıfa geçtiklerini bilmesiydi. Bu durum derslere karşı ilgiyi azalttı. Not verilme, sınav olsaydı çok daha verimli katılım olacağını düşünüyorum." (Ö.1)

"Öğretmenlerin kendi alanlarında yapılan uluslararası çalışmalara, gelişmelere ulaşabileceği bir portal kesinlikle olmalıdır. Bu biz ögretmenlerin EBA' ya olan ilgisini artıracaktır diye düşünüyorum. Bu şekilde her öğretmene özgü ve kendine ait alanlar oluşacaktır. Aynı zamanda ülke çapında her zümrenin birbiri ile etkileşimin olabildiği, kaynak, bilgi vs. paylaşımının olduğu bir modül kurulabilir." (Ö.6)

"Portalda ilk zamanlar donma yaşandı ögrenciler ve öğretmenler sisteme yabancı oldukları için girememe sıkıntısı yaşadılar ama zaman içinde problem çözüldü ben portaldan memnun kaldım herhangi bir eksiklik yaşamadım." (Ö.9)

"Illk başlarda gerek eğitim portalındaki aksakllklar gerekse biz öğretmenlerin bu portaldaki canlı derslere yabancı olmamızdan dolayı bir hayli zorluklar yaşadık. İlerleyen süreçte eğitim portalının güncellenmesi ve bizlerin derslerde tecrübe kazanmamız biraz olsun bizi rahatlattı. Ara ara bağlanamama, sistemden atılma gibi hatalar olmasina rağmen giderek sorunların daha aza indirildiği kanaatindeyim." (Ö.13)

"Portal zaylf ve yetersizdi. Son dönemde biraz düzeldi. Alt yapısının güçlendirilmesi ve ögrencileri de teknolojik olarak, bir daha böyle bir süreç yaşanırsa, donatmak gerekmektedir. Hiçbir öğrenci bir diğerinden eksik kalmamalıdır." (Ö.20)

Turkish Studies, 15(4) 
"Kullanılan sistem çok hızlı bir şekilde hayata geçirildiği için eksiklerinin olmasını normal karşıllyorum. Özellikle canlı derslere bağlanma konusunda dakikalarca bağlantı hatası yaşadık. Ancak güncellemelerle bu sorunlardan kurtulmanın çözümleri de sunuldu. Öğrencilerimiz bu süreçte tamamen derslerden uzak kalmadl, sistem sayesinde eğitimin uzaktan devam ettiğinin farkindaydllar." (Ö.23)

"Ebayaentegre edilmiş zoom uygulamasında, video oynatıcısını veya internet sayfasını açamadık. Ayrica ders esnasında öğrenci kameralarının açılması keyfi değil zorunlu olmalıydı, öğretmenin ders sirasinda ögrenciyi gözlemleyebilmesi etkili ders için önemliydi." (Ö.26)

"Ben hala bilgisayarımdan bağlanamiyorum. Telefonumdan bağlanarak derslerimi işliyorum. ve telefonumda kalem özelliği olmadı̆̆ından çok zorlandım. Hazırlıksız yakalanıldı sonuçta ilk günlerde bağlanmak daha zordu sonrasında ya bağlanan kişi sayısı azaldı ya da sistem iyileştirildi daha rahat bağlanmaya başladık." (Ö.28)

"Daha çok EBA kullandım. Bunun dışında kendi hazırladı̆̆ım etkinlikleri ve İl Milli Eğitim Müdürlüklerinin hazırlamış olduğu haftalık çalışmaları kullandım. Zoom programını bilgisayarımdan kullanabiliyordum. Ders saatlerini velilerle görüsserek kendim belirleyebiliyordum. Girdiğim tüm sinıflarla haftada 2 saat ders yaptım. Bu programı kullandı̆̆ım zaman katılımın daha iyi olduğunu düşünüyorum. Güvenlik sorunu gündeme gelince kapatmak zorunda kaldım. Okulumun ders atamasını bekledim. EBA canlı der süreci başladıktan sonra bilgisayarımı kullanamadım, telefondan derslere giriş yapmak zorunda kaldım. EBA eğitim bu zor süreçte kendini hızlı bir şekilde geliştirdiğini düşünüyorum. Öğretmen ve ögrencilere gerekli olan materyalleri hazırladı ve güncelledi. EBA TV'de ögrencinin gelişimi için farklı etkinliklere yer verdi. Her okul kendi ögrencilerine yönelik ders videoları hazırlayabilir. Bu ders videolar hazırlanırken gerekli tedbirler alınarak ögrencilerinde katılımı sağlanabilir. Öğretmenlere dijital içerik ve materyal geliştirme konusunda eğitim verilmelidir." (Ö.30)

\section{Görüşler}

Covid-19 Pandemi Uzaktan Eğitim Sürecinde Velilerden Alınan Dönütlerle İlgili

Araştırmaya katılan Türkçe öğretmenlerine uzaktan eğitim sürecinde öğrenci velilerinden destek, olumlu ya da olumsuz dönütler alıp almadıkları sorulmuştur. Türkçe öğretmenleri öğrenci velilerinin uzaktan eğitim sürecini desteklediklerini ifade etmiştir. Öğrenci velilerinin imkânları dâhilinde öğrencilerinin uzaktan eğitimlerini desteklemeye çalıştıkları, Türkçe öğretmenleriyle iletişim halinde oldukları anlaşılmaktadır. Türkçe öğretmenleri öğrenci velilerinin gayretleri nedeniyle kendilerine teşekkür ettiğini ifade etmiştir. Araştırmaya katılan Türkçe öğretmenleri öğrenci velilerinin, çocuklarının bilgisayar başında gereğinden fazla zaman geçirmek istediklerini, onları bilgisayardan, ekrandan uzaklaştırma noktasında tartışma yaşadıklarını ifade etmiştir. Öğretmenler genel olarak öğrenci velilerinin öğretmenlerin ilgisinden memnun olduğunu ancak canlı ders sistemi, eba bilişim ağı ile ilgili teknik sorunlar ve kısıtlamalardan şikâyetçi olduklarını ifade etmiştir. Veliler ücretsiz internet erişimi olduğu saatlerde canlı derslerin olmamasını, öğrencinin o saatte ebaportalına giriş hakkının olmamasını eleştirmiştir. Öğretmenlerin yanıtlarından doğrudan alıntılara aşağıda sunulmuştur.

"Veliler tarafindan olumlu dönütler aldım. Öğrencilerin derslerden geri kalmamaları için uzaktan eğitimi desteklediler. Verilen ödevlerin kontrollerine yardımcı oldular.”(Ö.2)

"Veliler ögrencilerin derslere katılmalarındaki isteksizliklerden yakındılar evde test çözdüremediklerini kitap okutamadıklarını söylediler dönütler genellikle olumsuzdu. Biz öğretmenlere gayretlerimizden dolayı teşekkür ettiler." (Ö.5)

"Velilerimiz özellikle canlı derslerin oldukça faydal olduğunu ve whatsapptan gönderdiğimiz ödevlerden, konu özetlerinden çok memnun olduklarını dile getirdiler. Velilerimiz imkanları 
dahilinde ögrencilerimizin canlı derslere, online denemelere katılmalarını sağladılar. Velilerimiz bu süreçte evde çocuklarının ders takibini yaptıkları için bu destek beni de memnun etti." (Ö.8)

"Canlı derse bağlanamayanlardan, yoğunluktan dolayı ebaya giriş yapamayanlardan ilk başlarda epey şikâyet geldi. Internet imkânı olmayanlar da vardı. Canlı derslere katılabilenler, internet, bilgisayar, telefon imkânı olanlar derslerden dolayı memnun oldukların ifade ettiler." (Ö.10)

"Öğrenci Whatsapp gruplarından ödevler göndermemiz, bilemedikleri sorulart yanıtlamamı, her hangi bir sorunla ilgili bizlere rahatça ulaşabildikleri için teşekkürlerini ileten veli ve ögrenci sayımız oldukça fazla. Şimdiye kadar çocuklar bu kadar uzun süre evde kalmamıştı. Veliler de çocuklarının dersleri anlayabilmeleri için bu kadar emek harcamamışt. Herkes için zor bir süreç oldu. Veliler sürece dâhil olmaya çalıştılar ancak çalışan anne ve babaların çocukları evde yalnız kaldığı için iletişsimsizler de yaşadık bazı velilerle." (Ö.12)

"Okullarda yapılan eğitime ara verilmesiyle birlikte yullardır var olan eğitim alışkanlıkları değişmiştir. Öğrenciler eğitim-öğretim süreçlerinin büyük kısmını okullarda ve ögretmenleriyle geçirirken klsa sürede ĕgitim-öğretim süreçleri eve taşınmıştır. Öğrencinin ĕgitim-öğretim süreçlerini evden takip etmesi velilerin de sürece daha fazla katılmaların beraberinde getirmistir. Ögrrencilerin dijital ĕgitim sürecinde akademik, sosyal ve psikolojik anlamda yaşadığl sorunlar ve aksaklıklar veliler tarafindan tarafima aktarılmıştır. Bu dönemde veli-öğretmen iletişiminin arttı̆̆ını söyleyebilirim. Öğrencinin ĕgitime verilen arada evde olduğu süreci veli gözetiminde geçirdiği düşünüldügünde velinin süreçle ilgili detaylar bildirmesi ögrenci için yaralı olmuştur. Bu süreçte yaşanılan zorluklar karşısında velilere ihtiyaç duyduklarl desteğin tarafimdan verildiğini düşünüyorum.” (Ö.18)

"Ebaya bağlanamamaktan epeyce şikâyet aldım. Ve maalesef ülkemizde evinde internet olmayan ögrencilerim olduğundan isteseler de bă̆lanamadıklarını söylediler. Evet tüm operatörler bedava internet verdiklerini söyledi ancak bazı ögrencilerin dersleri o internetin bedava olduğu sürelerde değilmiş. Bu yüzden yararlanamamışlar. Çalışan anne ve babalar bu süreçte sıkıntı yaşadı çocukları evde yalnız kaldiğı için. Veliler ellerinden geldiği kadar bize destek olmaya çalıştılar diyebilirim." (Ö.18)

"Velilerimiz memnun olduklarını dile getirdi. Evinde bilgisayarı olamayan veliler ise yaşadıkları zorlukları belirttiler. Bu süreçten olumsuz etkilendiklerini anlattılar. Çünkü bilgisayardan canlı ders dinleyebilen ögrenciler le evinde bilgisayar olmayan öğrenciler arasında fark oluştu maalesef." (Ö.20)

"Yaptığımız ĕgitimden, ilgimizden dolayı teşekkür mesajları aldım. Bizim öğretmen olarak çocuklarını yalnız bırakmayışımız velileri memnun etti." (Ö.22)

"Veliler bizi destekledi. Öğrencilerin evde verilen ödevleri yapmalarını ve derslere bağlanmaların takip ettiler. Her ikisi de çalışan velilerde ders takibi konusunda problemler oldu sadece. Onun dışında velilerden olumlu dönütler aldım." (Ö.28)

\section{Türkçe Öğretmenlerinin Bundan Sonraki Pandemi Süreci ile İlgili Görüşleri}

Araştırmaya katılan Türkçe öğretmenlerine bundan sonraki süreçle ilgili görüşleri sorulmuştur. Türkçe öğretmenleri bundan sonraki sürecin pandeminin seyrine göre şekil alabileceğini ifade etmiştir. Öğretmenler yanıtlarında uzaktan eğitimin yüz yüze eğitimin yerini asla tutmayacağını ancak deprem, salgın hastalıklar gibi durumlarda okulların tatil edilmesi halinde eğitimle ilgili hemen uygulanabilecek bir sistemin hazır olması gerektiğini belirtmiştir. Türkçe öğretmenleri Türkçe ders kitaplarının uzaktan eğitim süreçleri için yeniden yapılandırılmasının faydalı olacağını ifade etmiştir. Öğretmenler Türkçe ders kitaplarının bazı bölümlerinin dijital ortamlarla uyumlu olması gerektiğini söylemiştir. Türkçe ders kitaplarının EBA portalına entegre edilmesini ve ders kitabındaki tüm bölümlerin EBA portalından ödev verebilme, verilen ve çözülen ödevleri takip edebilecek şekle getirilmesi gerektiğini aktarmıştır. Araştırmaya katılan Türkçe

Turkish Studies, 15(4) 
öğretmenleri öğrencilere sanal ödevlerin verilebileceğini, dijital içeriklerin geliştirilmesi gerektiğini ve Türkçe ders kitaplarının bu dijital içeriklerle uyumlu olması gerektiğini ifade etmiştir. Türkçe öğretmenlerinin bundan sonraki pandemi süreci ile ilgili görüşleri Tablo 3 'tesunulmuştur.

Tablo 3: Türkçe Öğretmenlerinin Bundan Sonraki Pandemi Süreci ile İlgili Görüşleri

\begin{tabular}{ll}
\hline Uzaktan eğitim sürecinde yaşanan teknik aksaklıkların giderilmesi & 22 \\
\hline Uzaktan eğitimde hemen uygulanabilecek bir sistemin hazır olması & 14 \\
\hline Türkçe ders kitaplarının uzaktan eğitim süreçleri için yeniden yapılandırılması & 21 \\
\hline EBA canlı ders uygulamasının ve EBA'nın Türkçe ders kitaplarıyla entegre olması & 25 \\
\hline Türkçe ders kitaplarının dijital ortamlarla uyumlu olması & 22 \\
\hline
\end{tabular}

Araştırmaya katılan 22 Türkçe öğretmeni uzaktan eğitim sürecinde yaşanan teknik aksaklıkların giderilmesi gerektiğini ifade etmiştir. 25 katılımcı EBA canlı ders uygulamasının ve EBA'nın Türkçe ders kitaplarıyla entegre olması gerektiğini belirtmiștir.22 katılımcı Türkçe ders kitaplarının dijital ortamlarla uyumlu olması yönünde görüş beyan etmiştir. 21 Türkçe öğretmeni ise Türkçe ders kitaplarının uzaktan eğitim süreçleri için yeniden yapılandırılması gerektiğini belirtmiştir. Türkçe öğretmenlerinin yanıtlarından doğrudan alıntılar aşağıda sunulmuştur.

"Dersler elbette uzaktan eğitimle yapılabilir ancak sinıf ortamı kadar verimli olması mümkün değil, sanal olarak yapılabilir alanları var özellikle dinleme etkinliklerini sanal olarak ya da uzaktan eğitimle yapabiliriz ama dil becerilerinin tam să̆lanabilmesi için yüz yüze eğitim kaçınılmazdır. Uzaktan eğitim için ders kitaplarının yeniden yapılandırılması gerekir."(Ö.1)

"Son birkaç yılda EBA nın kullanılmaya başlaması zaten eğitimin artık dijitalleşmeye başladığını göstermişti. Önceden de EBA dan ögrrencilerimizle ödev, dosya paylaşımları yapsak da bu süreçte hem ögrenciler hem ögretmenler olarak çok daha etkin kullandık. EBA da çok fazla yardımcı kitabın ve ders kitaplarının bulunması bilgiye öğrencinin kolay erişmesini sağladı. Yüz yüze eğitimin ve sınıf ortamının etkisini elbette hiçbir şey tutamaz ancak ilerleyen süreçte kâğıt israfinın da önüne geçmek adına sanal ödevlere daha fazla yer verilebileceğini düşünüyorum.”(Ö.3)

"Bundan sonraki süreçte Covid-19 pandemisi devam ederse uzaktan eğitime devam edilebilir. Ama bunun için bütün ögrencilerin katılabilmesi săglanmalı ve süreçte değerlendirme yapılmall. Biz ögretmenler de uzaktan eğitim sürecinde öğrencilere okul dışında da nasıl ulaşabileceğimizi ve destek olabileceğimizi ögrendik. İlerleyen yıllarda teknolojiyle daha iç içe olarak hem okulda hem okul dışında da ögrencilerimize daha çok katkı sağlayabileceğiz.

Türkçe ders kitaplarının sanal ödevler içermesi demek her ögrencinin ve her ögretmenin teknolojik donanıma sahip olması demektir. Yine bu da ögrenciler ve okullar arasında farkllliklara neden olacaktır nedenle uzaktan eğitim ders kitaplarında değil, öğrencilere destek olarak kalmalı.” (Ö.5)

"Bundan sonraki süreçte uzaktan eğitim öğrenciler ve ögretmenler için daha verimli olacak şekilde düzenlemeler yapılarak devam etmelidir. Yüz yüze eğitimin yanı sıra güçlü bir eğitim öğretim portall olarak EBA kullanılmaya devam edilebilir. Böylece şimdi olduğu gibi bir sorunla karşılaştı̆̆ımızda ĕgitim öğretim sürecini en az kayıpla geçirebiliriz.” (Ö.7)

"Okul ve sınıf ortamındaki gibi verimli olabileceğini düşünmüyorum. Her öğrenci için uygun ögrenme sağlamayabilir diye düşünüyorum. Ĕger yapılacaksa da tatbiki ders kitaplarının ona göre hazırlanması gerekir diye düşünüyorum." (Ö.9)

"Uzaktan eğitim zorunluluk halleri durumunda kullanılabilecek bir süreç. Şöyleki konu tekrarı yapmak isteyen farklı öğretmenden konuyu dinlemek öğrenciler için devamlılığı sağlanabilir. Asla sinıf ortamının verdiği sosyal etkileşimi akademik başarıy veremez. Tabiki sanal ödev ya da görevlerle eğitim ögretim desteklenebilir." (Ö.11) 
"Bu şekilde sadece uzaktan eğitim yapılarak çok fazla verim alınabileceğini düşünmüyorum. İnsan sosyal bir varlıktır. Okulların eğitim, ögretimde en faydalı olduğu noktalardan biri de ögrencilerin okul ortaminda sosyalleşmesidir. Böylece bireysel yönleri kadar toplumsal yönleri de gelişmiş olur. Öğretmenlik mesleği her zaman önemini koruyacaktır. Türkçe ders kitaplarl uzaktan eğitim sürecine göre yeniden ele alınabilir. Arada sanal etkinlikler konulabilir. Çocuklar için farklılık olur, bazı konularda daha ĕglenceli hale bile getirir. Fakat ilkokul ve ortaokul çăğndaki çocukların sadece uzaktan eğitim alarak başarılı olacaklarını asla düşünmüyorum." (Ö.14)

"Açıkçası yüz yüze eğitimin başlamasını ne kadar istesem de korkmuyor değilim. Kalabalık bir ortam olan okulda ögrencilerimin ve kendi să̆llğımdan endişeliyim. Ancak bu süreç matematik eğitiminin bu yaş grubundaki ögrrenciler için uzaktan olamayacağını herkese kanıtlamıştır. Kitapların ele alınması gerektiğini düşünüyorum. Sanal ödevler ögrenciler için faydalı olabilir." (Ö.17)

"Derslerin sürekli olarak uzaktan yapılmasının yararlı olmadığını düşünüyorum. Öğretmenlerin bu süreçte Milli Eğitim Bakanlı̆̆ının uzaktan hizmet içi faaliyetlerine katılarak gereksinim duyduğu konularda kendini gelişstirmesi gerekir, Türkçe ders kitaplarının uzaktan eğitim sürecine göre yeniden ele alınması gerektiğini düşünüyorum. Ders kitaplarının belirli bölümlerinde ögrenciler için sanal ödev ve görevlendirmelerin yapılmasının yararlı olacağını düşünüyorum. ”(Ö.20)

"Evet dersler uzaktan yürütülebilir öğrencilerin imkânlart olduğu sürece. Öğretmenlere dijital içerik oluşturma konusunda eğitimler verilmelidir. Böylelikle kitaplara olan ihtiyaç giderek azalacaktır diye düşünüyorum. Evet, kitaplar yeniden ele alınmalıdır. Evet, sanal ödevler verilebilir.” (Ö.25)

“ Derslerin uzaktan eğitimle yapılmasının istenilen sonucu sağlamasında çeşitli sorunlar olabilir. Uzaktan ĕgitim sürecinde öğrenci çeşitli sinavlarla kontrol edilmelidir bence. Öğretmen ögrencisine rol modeldir, duruşu, bakışı, olaylara yaklaşımı, sevgisini paylaşımı onlar için bir örnektir. Uzaktan eğitimde bunları gerçekleştirmek mümkün değildir. Kitapların yeniden ele alınması elbette etkili olur, sanal ödevler verilebilir zaten dijital eğitime doğru kaylyor çağımız. Belki ilerleyen süreçte derslerin bir kısmı yüz yüze yapılmayacak.” (Ö.29)

\section{Sonuç Tartışma ve Öneriler}

Covid-19 pandemi uzaktan eğitim sürecinde Türkçe eğitiminin durumunu tespit etmek ve bu konuda Türkçe öğretmenlerinin görüşlerini ortaya çıkarmak amacıyla yapın bu çalışma uzman görüşleri doğrultusunda oluşturulan yarı yapılandırılmış görüşme formu ile yürütülmüştür. Türkiye deprem kuşağında yer almaktadır, bu nedenle sık sık depremler yaşanmaktadır. Doğal afetler, salgın hastalıklar vb. sebeplerden ötürü okulların tatil edilmesi, eğitime ara verilmesi gerektiği durumlarda alternatif eğtim uygulamalarının olması oldukça önemlidir. Yaşanılan pandemi döneminde mevcut eğitim sisteminin durumunun test edilebilmesi, bu tür durumlarda yaşanabilecek aksaklıkların ve sorunların tespit edilerek uzaktan eğitim süreçlerinin daha sağlıklı yürütülebilmesi adına bu çalışmaya benzer çalışmaların yapılması oldukça önemlidir. Bu araştırmanın amacı pandemi dönemi uzaktan eğitim sürecinde Türkçe eğitimin durumunu Türkçe öğretmenlerinin görüşleri doğrultusunda incelemek ve Türkçe öğretmenlerinin bu süreç hakkındaki fikirlerini ortaya koymaktır. Türkçe öğretmenlerinin görüşleri doğrultusunda çözüm önerileri getirebilmektir. Araştırmaya katılan 30 Türkçe öğretmenine uzaktan eğitim sürecinde Türkçe eğitiminin durumu ile ilgili görüşleri sorulmuştur. Araştırmaya katılan Türkçe öğretmenlerine okulların tatil edildiği pandemi döneminde Türkçe derslerini nasıl işledikleri sorulmuştur. Alınan yanıtlardan öğretmenlerin \%87'sinin okulların tatil edildiği pandemi döneminde Türkçe derslerini işlemeye çalıştı̆̆ı, öğrencilerin Türkçe eğitiminden kopmamaları için imkânlar dâhilinde çeşitli video ders programlarını ve çeşitli sosyal mesajlaşma uygulamalarını kullanarak öğrenciler ve öğrenci velileri ile iletişim halinde oldukları anlaşılmıştır. Eğitime ara verilen bu dönemde, Türkçe öğretmenlerinin zorunlu olmamalarına rağmen gönüllü bir şekilde kendi çabaları ile öğrencilerinin 
Türkçe eğitiminden uzak kalmamalarını sağlamaları Türkçe eğitimi adına sevindiricidir. Araştırmaya katılan Türkçe öğretmenleri EBA TV ile başlayan uzaktan eğitim sürecinin kendileri tarafindan Zoom, team link, skype gibi uygulamalarla canlı dersler şeklinde devam ettiğini, ilerleyen süreçte Millî Eğitim Bakanlı̆̆ı'nın EBA canlı ders uygulamasını hayata geçirmesiyle derslere buradan devam ettiklerini ifade etmişlerdir. Araştırmaya katılan Türkçe öğretmenleri whatsapp uygulaması gibi iletişim kanalları ile öğrencilere ödevlendirmeler yaptıklarını ifade etmiştir.

Araştırmaya katılan Türkçe öğretmenlerine uzaktan eğitim sürecinde Türkçe eğitimiyle ilgili yaşadıkları sorunları ifade etmeleri istenmiştir. Katılımcılar öğrencilerin bir kısmında bilgisayar, tablet gibi cihazların olmayışından canlı derslere katılamadıklarını ifade etmiştir. Öğrencilerin bir kısmında da internet erişimi olmayışı canlı derslere katılma konusunda sorun olarak belirtilmiştir. EBA canlı ders uygulamasının bağlantı sorunları olması, zaman sınırlaması olması gibi çeşitli aksaklıklarının olduğunu ifade eden katılımcılar bu olumsuzlukların zaman içinde azaldığını ifade etmiştir. Uzaktan eğitim sürecinde derslere katılımın öğrenciler ve öğretmenler tarafından gönüllülük esasına göre yürütülmesi Türkçe eğitimi adına bir bütünlügün oluşmamasına yol açmıştır. Araştırmaya katılan öğretmenler ayrıca velilerin bir kısmının bu süreçte ilgisiz olduğunu, öğrencileri bilgisayar başındayken takip etmediklerini, özellikle her ikisi de çalışan velilerin çocuklarının süreç için kontrolsüz kaldığını ifade etmiştir. Bu sürecin bazı öğrencilerde ekran bağımlılı̆̆ oluşmasına neden olduğunu ifade eden öğretmenler velilerin de bu konuda eğitilmesi gerektiğini belirtmiştir. Benzer çalışmalarda da internet bağlantısı ve çeşitli teknik aksaklıklar gibi nedenlerle, uzaktan eğitim süreci olumsuz etkilenmiştir (Birişçi,2013: 34). Benzer başka bir araştırmada da hizmet içi eğitimler video konferans yöntemiyle verilmiştir ve akabinde de öğretmen görüşleri alınmıştır. Altyapı ve etkileşim eksikliği gibi nedenlerden dolayı öğretmenlerin uzaktan eğitim yoluyla hizmet içi eğitimler hakkındaki görüşleri olumsuz çıkmıştır (Arslan ve Şahin,2013: 38).

Araştırmaya katılan Türkçe öğretmenlerine uzaktan eğitim sürecinde öğrencilerin derslere katılım düzeyleri ve bunun okuldaki derslerle kıyaslanması sorulmuştur. Ayrıca öğrencilerin uzaktan eğitim derslerine katılım düzeylerini arttırmak için neler yapılabileceği sorulmuştur. Derslere katılımın zorunlu olmadığı anlaşılınca önceden derse katılan öğrencilerin de katılımlarının azaldığını belirtmiştir. Bilgisayar ve bağlantı eksikliği nedeniyle canlı derslere katılım sağlayamayan öğrencilerin çokluğu katılan öğrencileri de olumsuz etkilemiştir. Araştırmaya katılan Türkçe öğretmenleri uzaktan eğitimde öğrencilerin derse katılım düzeylerini arttırabilmek için veli takibinin önemli olduğunu ve ayrıca bir değerlendirme sisteminin olmasının faydalı olabileceğini ifade etmiştir. Uzaktan eğitime katılan öğrencilere puan verilebileceğini belki de öğrenci karnesinde bununla ilgili bir ibarenin olmasının etkili olabileceğini belirtmişlerdir. Öğretmenler ayrıca bilgisayar ya da interneti olmayan öğrencilere tablet dağıtılmasının ve internet erişimi sağlanmasının uzaktan eğitim derslerine katılımı arttırıp firsat eşitliği sağlayabileceğini ifade etmiştir. Araştırmaya katılan Türkçe öğretmenlerine uzaktan eğitim sürecinin öğrencilerin Türkçe dersine olan ilgilerini ve akademik başarılarını ne düzeyde etkilediği sorulmuştur. Araştırmaya katılan Türkçe öğretmenleri, derslere katılımların düzenli olmadığını, bazı öğrencilerle hiç canlı derslerin yapılamadığını, ödevlendirme sisteminin olmadığını, ayrıca öğrencilerin derslere katılımlarının zorunlu olmadığını belirmiştir. Öğretmenler bu durumların öğrencilerin ilgi ve akademik düzeylerini olumsuz etkilediğini belirtmiştir. Araştırmaya katılan Türkçe öğretmenlerine uzaktan eğitim sürecinde kullanılan EBA canlı ders uygulaması ve eğitim portalı hakkındaki görüşleri sorulmuştur. Öğretmenler EBA canlı ders uygulamasının teknik sorunlarının süreç içinde öğrencileri olumsuz etkilediğini ifade etmiştir. Araştırmaya katılan Türkçe Öğretmenleri canlı derslerde zaman ve kota sınırı olmaması gerektiğini, istenilen her saatte eğitim portalının kullanılabilmesi gerektiğini ifade etmiştir. Türkçe öğretmenleri eğitim portalının alt yapısının güçlendirilmesi gerektiğini belirtmiş̧tir. Araştırmaya katılan Türkçe öğretmenleri öğrencilerin istedikleri saatte izleyebilecekleri ders videolarının olması gerektiğini, her okulun kendi 
öğrencilerine yönelik eğitim içerikleri ve videoları hazırlayabilmesinin faydalı olabileceğini ve bu konuda da öğretmenlere dijital içerik geliştirme eğitimlerinin verilmesinin önemli olduğunu ifade etmiştir.

Araştırmaya katılan Türkçe öğretmenlerine uzaktan eğitim sürecinde öğrenci velilerinden destek, olumlu ya da olumsuz dönütler alıp almadıkları sorulmuştur. Öğrenci velilerinin imkânları dâhilinde öğrencilerinin uzaktan eğitimlerini desteklemeye çalıştıkları, Türkçe öğretmenleriyle iletişim halinde oldukları anlaşılmaktadır. Türkçe öğretmenleri öğrenci velilerinin gayretleri nedeniyle kendilerine teşekkür ettiğini ifade etmiştir. Araştırmaya katılan Türkçe öğretmenlerine bundan sonraki süreçle ilgili görüşleri sorulmuştur. Öğretmenler yanıtlarında uzaktan eğitimin yüz yüze eğitimin yerini asla tutmayacağını ancak deprem, salgın hastalıklar gibi durumlarda okulların tatil edilmesi halinde eğitimle ilgili hemen uygulanabilecek bir sistemin hazır olması gerektiğini belirtmiştir. Türkçe öğretmenleri Türkçe ders kitaplarının uzaktan eğitim süreçleri için yeniden yapılandırılmasının faydalı olacağını ifade etmiştir. Öğretmenler Türkçe ders kitaplarının bazı bölümlerinin dijital ortamlarla uyumlu olması gerektiğini söylemiştir. Türkçe ders kitaplarının EBA portalına entegre edilmesini ve ders kitabındaki tüm bölümlerin EBA portalından ödev verebilme, verilen ve çözülen ödevleri takip edebilecek şekle getirilmesi gerektiğini aktarmıştır. Türkçe derslerinin bir kısmının belki ders kitabındaki bazı etkinliklerin dijital içerikler şeklinde geliştirilip uzaktan eğitim yoluyla yapılabilmesi Türkçe öğretmenleri tarafından ifade edilmiştir. Bu uygulama öğrencileri de memnun edecektir. Alan yazında buna benzer araştırmalarda öğrencilerin dersleri hem uzaktan eğitim hem de yüz yüze almak istedikleri ifade edilmiştir (Yalman,2013: 1403). Araştırmaya katılan Türkçe öğretmenleri öğrencilere sanal ödevlerin verilebileceğini, dijital içeriklerin geliştirilmesi gerektiğini ve Türkçe ders kitaplarının bu dijital içeriklerle uyumlu olması gerektiğini ifade etmiştir.

Araştırma sonuçları genel olarak değerlendirildiğinde bakanlığın hayata geçirdiği uzaktan eğitim sisteminin alt yap1 eksiklikleri olduğu görülmüştür. Tüm öğrencilerin aynı anda eğitim portalına girmesi sistemin kilitlenmesine sebep olmuştur. Bunun için altyapı ve bakım çalışmaları yapılarak sistem güçlendirilmelidir. Eğitim sistemimiz her an uzaktan eğitime hazır olmalıdır. Deprem, sel ve salgın hastalıklar gibi nedenlerle eğitim aksayınca uzaktan eğitim hemen devreye girip sorunsuzca yürütülebilmelidir. Öğrencilerin hepsinin bilgisayar ya da tabletlerinin olması ve internet erişimlerinin olması uzaktan eğitimin firsat eşitliği ilkesine göre yürütülmesi açısından oldukça önemlidir. Önceki yıllarda olduğu gibi öğrencilere tablet bilgisayar dağıtımı yapılabilir. Öğrencilerin maddi imkânsızlıklar sebebiyle bilgisayar, tablet ve internet erişimine sahip olamamaları gibi nedenlerin maddi desteklerle giderilmesi gerekmektedir (Kandemir, 2014: 1172). Araştırma sonuçları Türkçe ders kitaplarının dijital içeriklere uygunluğu ve eba eğitim portalına uygunluğu açısından eksiklikleri olduğunu ortaya çıkarmıştır. Araştırma sonuçlarına göre Türkçe öğretmenleri Türkçe ders kitaplarının EBA portalına entegre olmuş şekilde yeniden yapılandırılmasını istemektedir. Bu noktada Türkçe ders kitapları her zaman uzaktan eğitim yapılabilecek gibi sisteme entegre olmuş şekilde düzenlenmelidir. Araştırmaya katılan Türkçe öğretmenleri dijital içerik geliştirme konusunda eksiklikleri olduğunu ifade ettiklerinden öğretmenlere dijital içerik geliştirme konusunda eğitimler verilmesi oldukça faydalı olacaktır. Türkçe ders kitaplarının bilgisayar, tablet ve akıllı telefonlarla uyumlu olabilecek şekilde dijital içerik açısından güncellenmesi ve çeşitli dijital uygulamalara uyumlu olması oldukça önemlidir. Araştırma sonuçları öğrencilerin uzaktan eğitim sürecinde ekran bağımlılığı sorunu ile karşı karşıya kaldığını göstermiştir. Bunun olumsuz etkilerini ortadan kaldırmak için öğrenci ve öğrenci velilerine eğitimler verilmesi faydalı olacaktır. Öğrencilerin dijital ve etkileşimli kitaplara karş1 ilgileri vardır (Duran ve Topbaşoğlu, 2015: 531). Öğrencilerin kitap okuma seviyelerini arttıracak, kitap okumaya karş1 olan ilgilerini arttıracak dijital metinlerin, kitap okuma uygulamalarının geliştirilmesi ve bu konuda çalışmaların yapılması kitap okuma alışkanlığı açısından oldukça yararlı olacaktır. 


\section{Kaynakça}

Aktay, S. ve Keskin, T. (2016). Eğitim bilişim ağı incelemesi. Eğitim Kuram ve Uygulama Araştırma Dergisi, 2(3), 27-44.

Arar, A. (1999). Uzaktan eğitimin tarihsel gelişimi, uzaktan eğitim uygulama modelleri ve maliyetleri. Birinci Uzaktan Eğitim Sempozyumu 15-16 Kasım 1999, Ankara: Kara Kuvvetleri Ĕgitim ve Doktrin Komutanlı̆̆.

Arslan, H. ve Şahin, I. (2013). Hizmet içi eğitimlerin video konferans sistemiyle verilmesine yönelik öğretmen görüşleri. Journal of Instructional Technologies \&TeacherEducation JITTE Vol.1 No3 (2013),34-41.

Aydınözü, D., Sözcü, U. ve Akbaş, V. (2016). Coğrafya öğretiminde Eba içeriklerinin öğrenci başarısına etkisi. Karadeniz Sosyal Bilimler Dergisi, 8(15),339-357.

Birişçi, S. (2013). Video konferans tabanlı uzaktan eğitime ilişkin öğrenci tutumları ve görüşleri. Journal of Instructional Technologies \&TeacherEducation JITTE Vol.1 No2,24-40

Cemil, İ. (2013). Dicle Üniversitesi öğretim üyelerinin uzaktan eğitim konusundaki görüşlerinin değerlendirilmesi. Elektronik eğitim bilimleri dergisi. Yll:2013,C:2(4),66-73.

Duran, E. ve Topbaşoğlu, N. (2015). Dijital-etkileşimli öyküleyici metinler ve anlama.TurkishStudies, 10/11, 519-532. http://dx.doi.org/10.7827/TurkishStudies.8550

Fidan. N. (2012). Okulda ögrenme ve ögretme. Pegem.

Eba. (2020) "Depremzede öğrenciler Eba'yaadeapte oldu," son güncelleme 12 Haziran, 2020, https://www.haberturk.com/elazig-haberleri/76875415-depremzede-ogrencilerebaya-adapte-oldu

Kandemir, O. (2015). Türkiye'de yükseköğretim düzeyinde uzaktan eğitim uygulamalanı: eğitimde fırsat eşitliği ve ekonomik kalkınma. Turkish Studies, 9/5, 1155-1176. http://dx.doi.org/10.7827/TurkishStudies.6850

Kunç, Ş. ve Varol, A. (1994). 21. yüzyıl eğitiminde teknoloji kullanımı ve mesleki teknik eğitim. Endüstriyel Teknoloji, Bilimsel ve Teknik Dergi, Cilt 1, Sayı 1, Kasım 1994, S: $41-46$

Miles, M. B. And Huberman, A. M. (1994). Qualitative Data Analysis. Thousand Oaks, Sage Publication.

Papi, C. ve Büyükaslan, A. (2007). Türkiye ve Fransa'daki uzaktan eğitimde gelişmeler: hangi eğitim hakkı. Marsilya: Colloque Tice Mediterranee - Uzaktan Ĕ̆itimde İnsan / Değisşim Sorunsall.

Punch, F. K. (2014). Sosyal araştırmalara giriş nicel ve nitel yaklaşımlar (Çev: Bayrak, D., Arslan, H.B. ve Akyüz, Z.). Siyasal Kitabevi.

Tüysüz, C. ve Çümen, V. (2016). Eba ders web sitesine ilişkin ortaokul öğrencilerinin görüşleri, Uşak Üniversitesi Sosyal Bilimler Dergisi 9/3, 278-296.

Yalman, O. (2013). Eğitim fakültesi öğrencilerinin bilgisayar destekli uzaktan eğitim sistemi memnuniyet düzeyleri. Turkish Studies, 8/8, 1395-1406. http://dx.doi.org/10.7827/TurkishStudies.5357

Yalın H. İ. (2009). Öğretim teknolojileri ve materyal geliştirme. Nobel Akademik Yayıncılık.

Yıldırım, A. ve Şimşek, H. (2018). Sosyal bilimlerde nitel araştırma yöntemleri. Seçkin Yayınc1lik. 